\title{
Introduction of the Archimedean Screw Pump to East Asia during the Seventeenth and Eighteenth Centuries
}

\author{
Albert Koenig 黄立人 1
}

(Department of Civil Engineering, The University of Hong Kong, Hong Kong, China)

\begin{abstract}
The Jesuits played an important role in the transmission of Western science and technology to China during the seventeenth and eighteenth centuries, though their impact on water technology has received scant attention thus far. As a case in point, Sabatino de Ursis, Society of Jesus 熊三拔, in collaboration with the Chinese official Xu Guangqi 徐光啟, published in 1612 Hydraulic Methods of the Far West (Taixi shuifa 泰西水 法), the earliest book in China on Western water-lifting devices, which contained a detailed description of the Archimedean screw pump. While the impact of the Archimedean screw pump in China and Korea remained rather limited, the screw pump was used to drain water from gold mines in the Japanese Sado Island from as early as 1637. This fact became known in the West only in the very late 1800s when hand-colored picture scrolls about the Japanese gold mining process became available. These scrolls show various applications of Archimedean screw, which apparently were made according to the manufacturing instructions in Hydraulic Methods of the Far West.
\end{abstract}

Keywords: Hydraulic Methods of the Far West (Taixi shuifa 泰西水法), Archimedean screw pump, Jesuits, China, Korea, Japan

摘 要: 耶稣会士在 17 和 18 世纪西方科学技术向中国的传播过程中起到了重要作用, 但他们对水利技术的影响却未得到足够的关注。例如，传教士熊三拔与中国官员徐光启 合著了《泰西水法》(1612 年), 这是中国最早介绍西方提水装置的书籍, 其中详细描述 了阿基米德螺旋洜。阿基米德螺旋䈋在中国和朝鲜的影响较为有限, 但就日本而言, 这 种螺旋泵早在 1637 年就用于佐渡岛的金矿排水。19 世纪后期, 西方人接触到描绘日本 采金过程的手工着色画卷，这才了解阿基米德螺旋洜在日本的应用。这些画卷揭示了阿

\footnotetext{
* In this issue of CAHST, the book title Taixi shuifa 泰西水法 has been translated differently by the authors of two separate articles, one as Hydraulic Methods of the Far West in this article, the other as Hydromethods of the Great West in "Shared Ideas, Divergent Approaches: The Hydromethods of the Great West (Taixi shuifa 泰西水法) and the Question of Tides." CAHST would like to retain these translations as they are, so as to highlight the difficulties in translating such titles and the authors' differing interpretations. (This article was copyedited by Elizabeth Hughes.)

1 Research interests: Transfer of Western water technology to China from the seventeenth to the early twentieth century, history of Chinese water civilization, environmental engineering. Email: kalbert@hku.hk
} 
基米德螺旋泵的各类应用, 而相关知识显然源自《泰西水法》中的制作说明。

关键词: 《泰西水法》, 阿基米德螺旋泵, 耶稣会士, 中国, 朝鲜, 日本

\section{Introduction}

Tn the summer of 1689, Gottfried Wilhelm Leibniz (1646-1716) met the Italian Jesuit Claudio Filippo Grimaldi, Society of Jesus 閔明我 (1638-1710), who had lived in China since 1669, in Rome. Leibniz was very interested in all matters pertaining to China and had prepared a catalogue of thirty questions, some of them dealing with Chinese technology and science, which Leibniz thought might be superior to the West because of its older civilization. Among other things, Leibniz asked about horizontal windmills, and whether the Chinese knew about pumps and the Archimedean water screw, but he failed to record the answers during the brief conversation (Leibniz 2006). Leibniz was probably most curious about these technologies because of his own recently failed water management project of 1680-1685/6 for the German Harz mines, wherein he had proposed a Chinese horizontal windmill driving an Archimedean screw pump (Gottschalk 2007). Apparently, Leibniz was not aware that Archimedean screw pumps had already been made known in China by Sabatino de Ursis, SJ 熊三拔 (1575-1620). In 1612, Ursis, in collaboration with the Chinese official Xu Guangqi 徐光 啟 (1562-1633), published Hydraulic Methods of the Far West (Taixi shuifa 泰西水法), the earliest book in China on Western water-lifting devices. It contained a description of the Archimedean screw pump together with a detailed construction plan. This paper presents the crucial role of Hydraulic Methods of the Far West in transmitting the Archimedean screw pumping technology to East Asia, with its most successful and most surprising application occurring in Japan. Focus is only on the Archimedean water screw; the screw as one of the ancient simple machines (Guidobaldo [Giuidobaldo] del Monte 1577) and its introduction to China (Halsberghe 2011) are not covered in this paper.

\section{Western background}

The Archimedean screw pump can be described as a water-lifting device consisting of a screw inside an inclined hollow pipe, the so-called casing. The screw is rotated inside the stationary casing or, if fused with the casing, both are rotated together. Until the advent of modern times, the screw was usually turned by manual labor or animal power. The invention of the screw pump is traditionally attributed to the Greek scientist Archimedes of Syracuse (287-212 BCE) during his stay in Egypt (Simms 1995, 17:45-111). The only source for this story are two passages in Bibliotheke (known in Latin as Bibliotheca historica $=$ The Library of History) by the Greek historian Diodorus 
of Sicily (ca. first century BCE): (i) "For since it [the delta of the Nile River] is alluvial soil and well watered, it produces many crops of every kind, inasmuch as the river by its annual rise regularly deposits on it fresh slime, and the inhabitants easily irrigate its whole area by means of a contrivance which was invented by Archimedes of Syracuse and is called, after its shape, a screw" (Book I, 34.2), and (ii):

what is the most surprising thing of all, they [Roman slaves] draw out the water of the streams they encounter [in Spanish mines] by means of what is called by men the Egyptian screw, which was invented by Archimedes of Syracuse at the time of his visit to Egypt; and by the use of such screws they carry the water in successive lifts as far as the entrance, drying up in this way the spot where they are digging and making it well suited to the furtherance of their operations. Since this machine is an exceptionally ingenious device, an enormous amount of water is thrown out, to one's astonishment, by means of a trifling amount of labor, and all the water from such rivers is brought up easily and from the depths and poured out on the surface. And a man may well marvel at the inventiveness of the craftsman [Archimedes], in connection not only with this invention but with many other greater ones as well, the fame of which has encompassed the entire inhabited world. (Book V, 37.3-4). (Diodorus Siculus 1939)

Agricultural irrigation and drainage of mines were thus the two main applications of the screw pump. According to the Roman military architect and engineer Marcus Pollio Vitruvius (ca. 80-70 BCE-after ca. 15 BCE), another important application of the screw pump was in military engineering as a dewatering machine. Vitruvius's seminal work De architectura, known today as The Ten Books of Architecture (Vitruvius 1960), provides in Book X, Chapter 6 the first and only detailed description in antiquity of the wooden water screw, without mentioning the name of Archimedes, and gives precise guidelines for its manufacture. The water screw of Vitruvius was of the casing-tube type, whereby helicoidal blades are attached to a central inner cylinder and an outer cylinder, with the entire structure being rotated. The original Latin text on the water screw is shown in Appendix 1, together with an English translation. More information on Vitruvius's life and the importance of his work is found in Cigola and Ceccarelli (2014). However, it is not known how widespread the use of Archimedean screw pumps in the Roman Empire was in reality. Archaeologists found some visual representations of such pumps as well as relics in Roman mines (Forbes 1966, 214-223; Oleson 1984, 291-301).

Archimedes of Syracuse was a Greek mathematician, physicist, engineer, inventor, and astronomer. Besides the screw pump, he also invented many other machines, thus contributing greatly to the practical and theoretical advancement of mechanics. A huge body of literature has already been written about Archimedes and his enduring influence over the centuries on mathematics, science, and engineering, hence the 
excellent overviews of Paipetis and Ceccarelli (2010) and Rorres (2017) may suffice to provide a broad introduction about his contributions and legacy in modern times. Furthermore, Rorres (1995) created a continually updated and expanded website on all aspects of Archimedes's work, which is well worth visiting. ${ }^{2}$ More substantial information on Archimedes the engineer and/or mechanical engineer is found in Simms (1995) and Ceccarelli (2014), respectively. Moreover, Simms (2010a; 2010b; 2010c) authored the most comprehensive treatise ever on the history of the Archimedean screw pump. He tracks the screw's use from its origin to its current application in reverse-flow mode for power generation, which Branca (1629) had proposed as early as 1629. Koutsier and Blauwendraat (2004) reviewed the numerous attempts to find the best design of the Archimedean screw pump, citing practitioners and scientists like Vitruvius, Cardano, Leonardo da Vinci, Bernoulli, Euler, and more. The first theoretical analyses can be attributed to Galileo Galilei (1634) and Guidobaldo del Monte (1615). Galileo discovered the important fact that the angle of the water-raising screw must be tilted more than the angle of the screw blade on the central axis, otherwise no water would flow. The latest analytical attempt was reported by Rorres (2000), who considered three external (outer radius, length, and slope) and three internal parameters (inner radius, number of blades, and the pitch of the blades) to derive a formula to obtain the maximum volume of water lifted in one turn of the screw. However, he was only able to obtain an approximate solution, and no exact formula for its design exists until today.

It is well known that after the fall of the Roman Empire much technological knowledge fell into disregard or was lost. Fortunately, Vitruvius's De architectura, which contained the only account of the Archimedean screw pump in antiquity, was not lost, despite a widespread belief to the contrary. Manuscripts of De architectura were copied and stored in many monasteries. When Krinsky (1967) conducted an extensive search for medieval manuscripts of Vitruvius's De architectura, she found that many monastery libraries held copies as early as the eleventh century. At present, seventyeight manuscripts containing the entire text or excerpts are still extant in modern libraries and museums in eleven countries, thirty-eight of them in Italy and the Vatican City, written between 779 and circa 1500. Lohrmann (2006) has shown that knowledge of the Archimedean screw pump was available to quite a number of scholars during medieval times and was actually applied, although to a limited extent. "During the 15th century in Italy, it was not difficult to get access to the Vitruvius texts" (Krinsky 1967). It was a time when early humanists searched for and "rediscovered" many old handwritten manuscripts of classical works in ancient monasteries. In 1416, the eminent Florentine humanist Poggio Bracciolini (1380-1459), while attending the Council of

2 https://www.math.nyu.edu/ crorres/Archimedes/Screw/SourcesScrew.html. 
Constance (1414-1418), found between sessions a manuscript of De architectura in the library of the nearby Saint Gall Abbey in Switzerland. He had it transcribed and so ultimately contributed to its diffusion throughout the West. Shortly thereafter, Johannes Gutenberg (ca. 1400-1460) introduced the printing press to Europe (1439), starting a so-called printing revolution, which allowed knowledge to be rapidly and widely disseminated through books. De architectura, the only remaining book on architecture from antiquity, was first printed in 1486, followed by many more editions and translations (Cigola and Ceccarelli 2014). Digitized versions of most early editions and translations can be found in the database Architectura (University of Tours n.d.). Since the original illustrations by Vitruvius were lost, new illustrations were included based on the old descriptions. The most important early editions containing an illustration of the Archimedean screw pump are listed below (see Figures 1 and 2).

Table 1: The most important early editions containing an illustration of the Archimedean screw pump

Fra Giovanni Giocondo, OFM (1511, 1513, 1522, 1523) M. Vitruvii de architectura libri decem

Cesare Cesariano (1521) Di Lucio Vitruvio Pollione de architectura libri decem

Francesco Lucio Durantino $(1524,1535)$ M. L. Vitruuio Pollione de architectura

Walther Hermann Ryff $(1543,1548,1575,1614)$ Vitruvii . . de architectura libri decem

Jean Martin $(1547,1572,1618)$ Architecture, ou Art de bien bastir du Marc Vitruve Pollion

Daniele Barbaro $(1556,1567,1584,1629)$ I Dieci Libri dell' Architettora di M. Vitrvoio

Daniele Barbaro (1567) De architectura libri decem

Miguel de Urrea (1582) M. Vitruvio Pollion de architectura

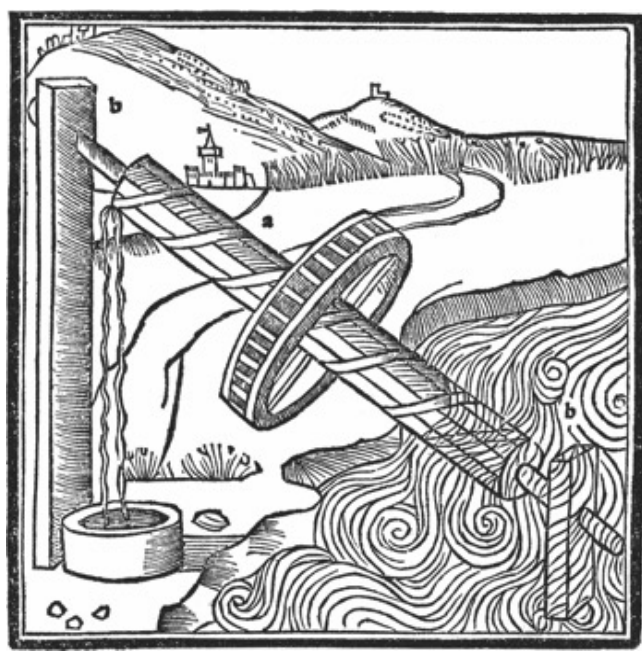

Figure 1: Fra Giovanni Giocondo, OFM (1511).

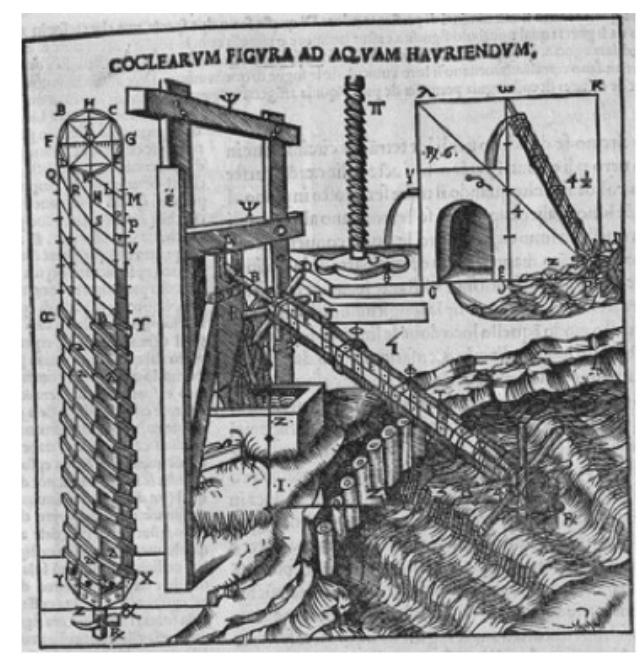

Figure 2: Cesare Cesariano (1521). 
In addition, the Archimedean screw was depicted in other early printed books such as military books, general books, or the new genre of machinery books. Some books containing an illustration are indicated below (see Figures 3 to 6):

Table 2: Some books containing an illustration of the Archimedean screw

Roberto Valturio $(1472,1482,1535$, etc.) De re militari

Flavius Vegetius Renatus $(1475,1529,1534$, etc.) De re militari [=Epitoma rei militaris]

Gerolamo Cardano $(1554 ; 1580)$ De subtilitate

A

Giuseppe Ceredi (1567) Tre discorsi sopra il modo d' alzar acque da' looghi bassi

Jean Errard de Bar-le-Duc (1584) Le premier livre des instruments mathematiques mechaniques

Agostino Ramelli (1588) Le Diverse Et Artificiose Machine Del Capitano Agostino

Heinrich Zeising (1610) Theatrum machinarum, vol. 2

Guidobaldo [Guido Ubaldo] del Monte (1615) De cochlea libri quatuor

A

Salomon de Caus (1615) Les raisons des forces mouvantes

Robert Fludd (1618) Tractatus secundus de naturae simia

Giovanni Branca (1629) Le machine

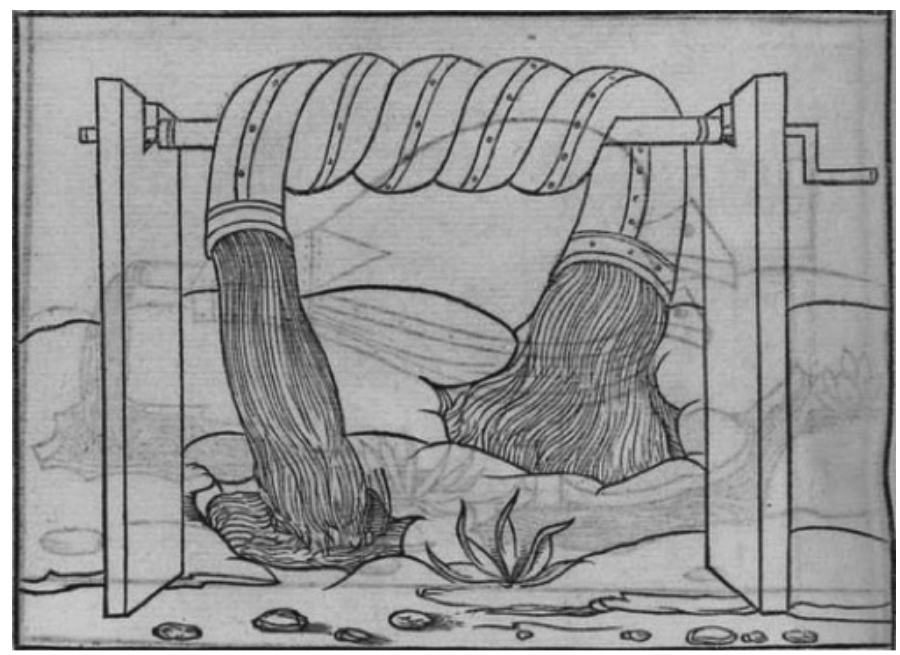

Figure 3: Roberto Valturio (1472).

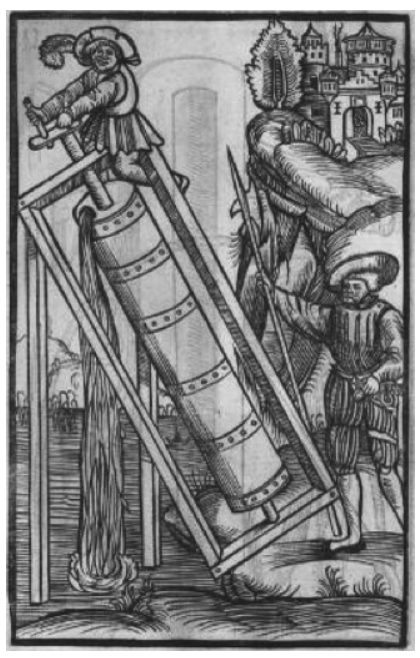

Figure 4: Flavius Vegetius

Renatus (1529).

Besides printed books, some manuscripts and sketchbooks were also found to contain illustrations of the Archimedean screw, a few of them in beautiful hand coloring. However, while some of the manuscripts were well circulated at the time (Ceccarelli 2008), others were barely known to a larger public, and some of them were discovered only recently, for example, Gruter ([1424] 2006), Bartoli (Lamberini 2011), and Lobato del Canto (García Tapia and García-Diego [ca. 1585] 1987) (Table 3). 


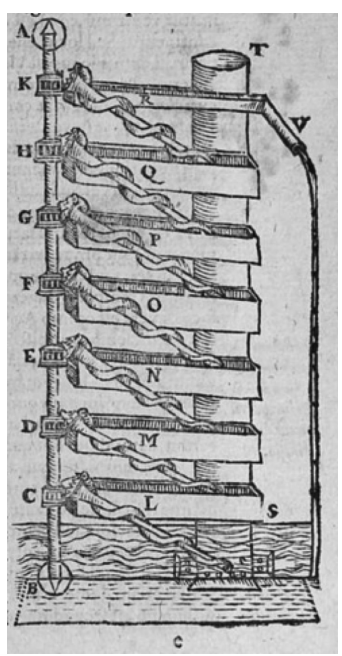

Figure 5: "Machina Augustana" (Gerolamo Cardano 1554, 20). ${ }^{3}$

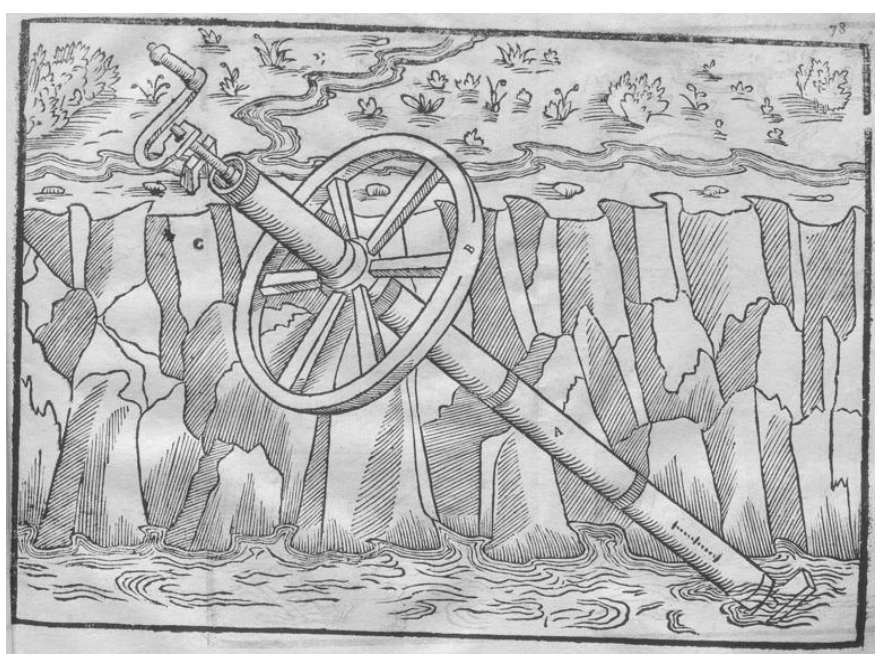

Figure 6: Giuseppe Ceredi (1567).

Table 3: Some manuscripts and sketchbooks containing illustrations of the Archimedean screw

Konrad Kyeser (ca. 1405) Bellifortis

Konrad Gruter (1424) De machinis et rebus mechanicis

Mariano di Jacopo, detto Taccola (ca. 1430) De ingeneis

Bonaccorso Ghiberti (1472-1482) Zibaldone

Francesco di Giorgio Martini (ca. 1484) Trattati de architettura ingenieria e arte militare

Leonardo da Vinci (1503) Codex Atlanticus

Anon. (ca. 1520) Ingenieurkunst- und Wunderbuch, Weimar

Taqi al-Din (1551) Al-Turuq al-Saniya fì al-'älat al-rūhaniya

Cosimo Bartoli (ca. 1567-1568) Raccolta di varie machine

Francisco Lobato del Canto (ca. 1530-ca. 1589) Manuscrito

Giovanni Antonio Nigrone (1585-1603) Scritti e disegni

Pseudo-Juanelo Turriano (ca. 1595) Los veínte y un libros de los ingenious

Galileo Galilei (1599) Le mecaniche

Over time, configurations other than the Vitruvian casing-tube screw evolved, the most important examples being the tube screw (in which helicoidal blades are attached to an inner cylinder and rotated in a fixed outer cylinder) and the spiral screw (in which helical tubes are wrapped around and attached to a central inner cylinder, with the entire structure being rotated), as seen in the works of Taccola, Valturi, and Leonardo (Nuernbergk 2017). In modern times, the trough screw (in which helicoidal blades are attached to an inner cylinder and rotated in a fixed U-shaped trough that is open to the surrounding air) is predominantly used (Nuernbergk 2017).

Surprisingly, the name of Archimedes is scarcely mentioned in books or manuscripts (indicated in the above lists by the letter A). Cardano (1554) seems to have

3 Also available at https://www.loc.gov/resource/rbc0001.2010gen23471/?st=gallery. 
been the first person in modern times to make reference to Diodorus of Sicily and use the term Archimedean screw (cochlea Archimedis). This assertion is supported by a claim in his autobiography (Cardano 1654, 8) that in his youth (around 1510) a smith named Galeazzo Rosso had discovered (invenit) the screw of Archimedes before the works of Archimedes had been published. As far as Archimedean screw pumps in practice are concerned, only Gruter, Cardano, Ceredi, and Barbaro (1556; 1584) reported having seen them in operation: Gruter in Padua and Venice, Cardano in Augsburg (the famous machina Augustana, a septuple Archimedean screw), and Barbaro in the vicinity of Venice. Ceredi manufactured his own screws. At one time, the young Michelangelo attempted to build an Archimedean screw pump for a duke but failed (Ceredi 1567, 6364). In fact, Ceredi was probably the only sixteenth-century engineer thoroughly acquainted with the design and operation of the Archimedean screw pump, which he consistently called "Chiocciola di Vitruvio" (= Cochlea Vitruvii). He even obtained patents in various cities on an improved and more efficient design. Compared to other hydraulic machines, he claimed a preference for the cochlea because of its safe operation, easy manufacture, and low-cost maintenance, as well as economic and agricultural benefits. However, he does not seem to have found many customers (Traetta 2019).

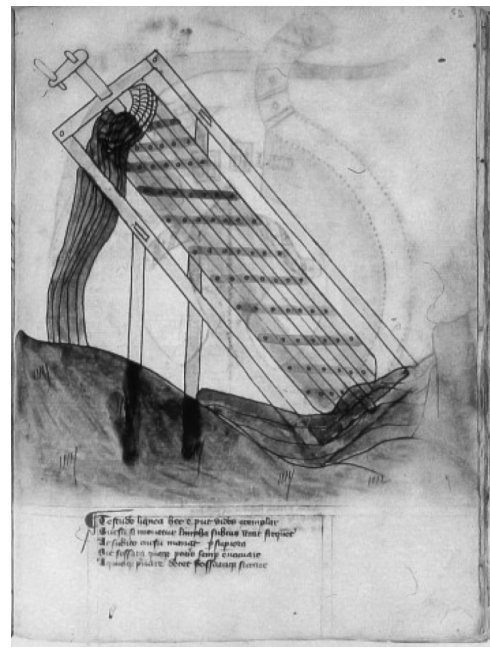

Figure 7: Kyeser ([1405] 1967)

(Courtesy of the MPIWG). ${ }^{4}$

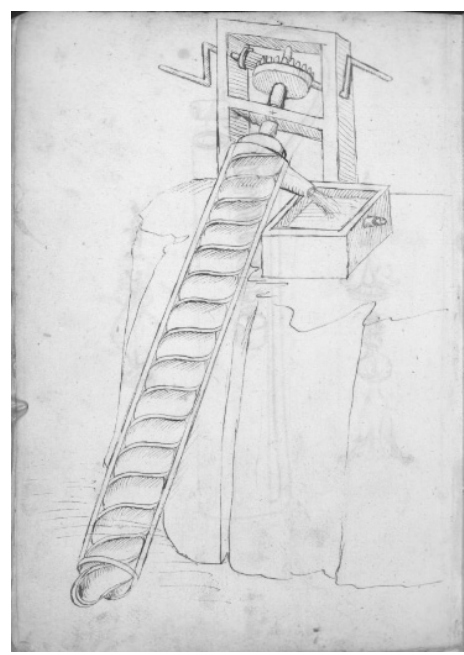

Figure 8: Mariano de Jacopo detto Taccola (ca. 1430) (Courtesy of British Library, MS 34113, f.170v). ${ }^{5}$

This lack of actual knowledge of the Archimedean screw pump is reflected in several drawings in early works, showing obviously non-functioning designs (Valturio

4 http://dmd.mpiwg-berlin.mpg.de/home.

5 For excerpts of De ingeneis (1433) and de Machinis (1449) (by Mariano de Jacopo detto Taccola) and Codicetto (by Francesco di Giorgio, 1460-70?), see http://www.bl.uk/manuscripts/Viewer. aspx?ref=add_ms_34113_fs001r. 
1472; Vegetius 1529; Kyeser [1405] 1967; Taccola ca. 1430). Based on the above, it may be safely inferred that Archimedean screw pumps were not commonly used in Europe before 1600. Around the same time, the first Europeans reached China by sea.

\section{Archimedean screw pumps in China}

After the first Jesuit missionaries entered China in 1582, they soon discovered that access to the ruling literati class was best achieved via the introduction of European science and technology. To this purpose, the missionary Matteo Ricci, SJ 利瑪竇 (15521610) initiated the establishment of a comprehensive library of Western books in Peking, among them many on the emerging area of hydrotechnics (Koenig 2014, 251-264). The Western books would thus serve the missionary efforts as important source materials for the transmission of Western knowledge through translations and publications. Ricci himself, together with the high-ranking Chinese scholar-official and prominent early convert Xu Guangqi 徐光啟 (1562-1633), is credited with the introduction of Euclidian geometry to China through the publication in 1607 of Elements of Geometry (Jihe yuanben 幾何原本). Ricci wrote in the preface: “There is also a subdivision [of geometry] that gives guidance to the trades and crafts that work with water, earth, stone or wood; . . . it digs canals and lets springs flow. ... There is also a subdivision that produces ingenious methods . . . to improve the drainage of flooded fields and to allow irrigation of arid land" (Engelfriet 1998, 455). This was the beginning of Jesuit interest in hydraulic applications to China. While the Jesuit transfer of knowledge from Europe to China has been extensively reviewed regarding sciences like astronomy, mathematics (Standaert 2003), or machinery design (Zhang 2017), their hydrotechnical activities in China have rarely been discussed (Koenig 2018). One of the most interesting cases is the Jesuit introduction of the Archimedean screw pump to China and how this knowledge spread further to Korea and Japan. Careful research revealed three books with descriptions of the Archimedean screw pump, which were published by the Jesuits in China in collaboration with Chinese literati. These books played an important role in the transfer of this particular Western technology to China.

\subsection{Hydraulic Methods of the Far West (Taixi shuifa 泰西水法) (1612)}

Hydraulic Methods of the Far West is the earliest book on Western hydrotechnics in China and introduces three new water-lifting devices all hitherto unknown in China: the double-tube reciprocating pump of Ctesibius (force pump), the single-tube reciprocating pump (suction pump), and the Archimedean screw pump. It was written in China in 1612 by the Italian Jesuit Sabatino de Ursis, SJ, 熊三拔 (1575-1620), together with the aforementioned $\mathrm{Xu}$ Guangqi, with the aim of presenting novel 
Western water-lifting machines for use in agriculture. Bartoli $(1663,545-548)$ reported that Ursis had previously built models of hydraulic machines for raising water, most probably the ones described in his book, which sparked the interest of many highranking mandarins and eunuchs from the Imperial Court due to their novelty and ingenious design. He also gifted models of the machines to officials and sent hydraulic machines to various cities for the benefit of the people. Based on this big success, Ricci and $\mathrm{Xu}$ Guangqi, who himself had a great personal interest in improving agriculture, suggested Ursis publish a treatise on hydraulic machines. ${ }^{6}$

Regarding the Archimedean screw, Ursis provided a comprehensive description, which can be traced back to the Latin and Italian Vitruvius editions by Barbaro (1567; 1584). Both were held in the Jesuit library in Peking (Verhaeren 1949). Figures 9.1-9.2 convincingly show that the illustration of the wooden Archimedean screw in Hydraulic Methods of the Far West matched the one in the Barbaro editions (Cigola and Fang 2016). Moreover, Ursis made detailed construction drawings with measurements based on Vitruvius's description, such as could not be found in any contemporary Western book (Figure 10). He even included a small drawing of the 5:4:3 Pythagorean right-angled triangle that, according to Vitruvius, corresponded to the ideal inclination of the Archimedean screw pump. With the help of Xu Guangqi, a classical Chinese name was chosen for the screw pump, namely longweiche 龍尾車, or the dragon tail machine. This

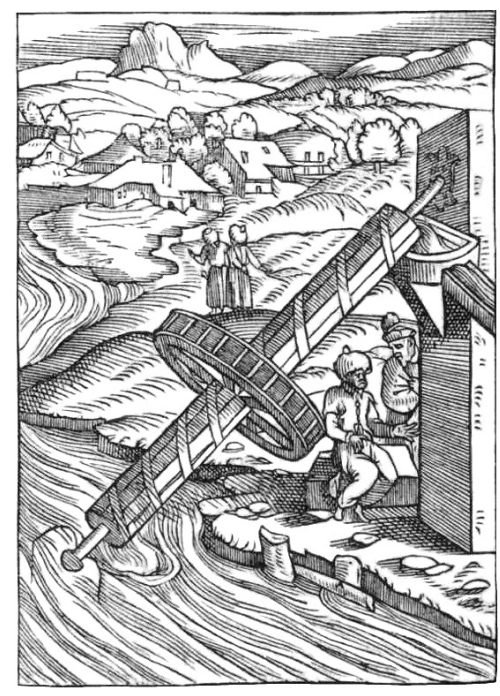

Figure 9.1: Archimedean screw pump (Barbaro 1567).

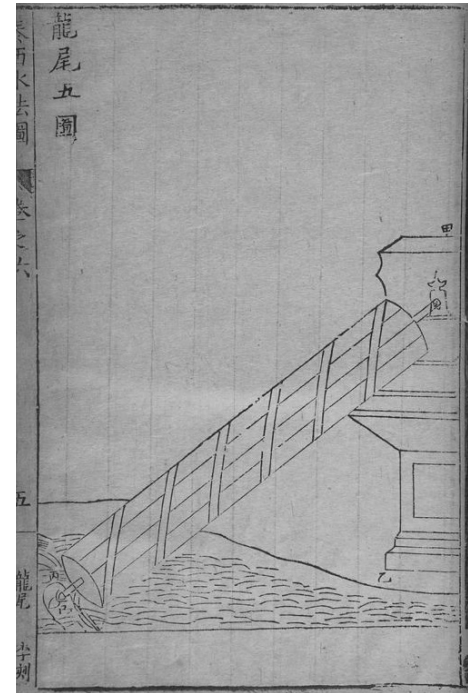

Figure 9.2: Longweiche 龍尾車 [dragon tail pump]) in Hydraulic Methods of the Far West (Ursis and Xu 1612).

6 Another version reports that the models of the hydraulic pumps were built by Sabatino de Ursis together with the Spanish Jesuit Diego de Pantoja (see 3.2) in 1612, after the death of Ricci (see 3.2) (Soto Artuñedo 2018, 134). 
name somewhat imitated the name of a widely used Chinese water-lifting device, the square-pallet-pump named longguche 龍骨車, or the dragon bone machine. Interestingly, Ursis failed to mention the name of Archimedes even though Barbaro had listed it (Ursis and $\mathrm{Xu} \mathrm{1612).}$
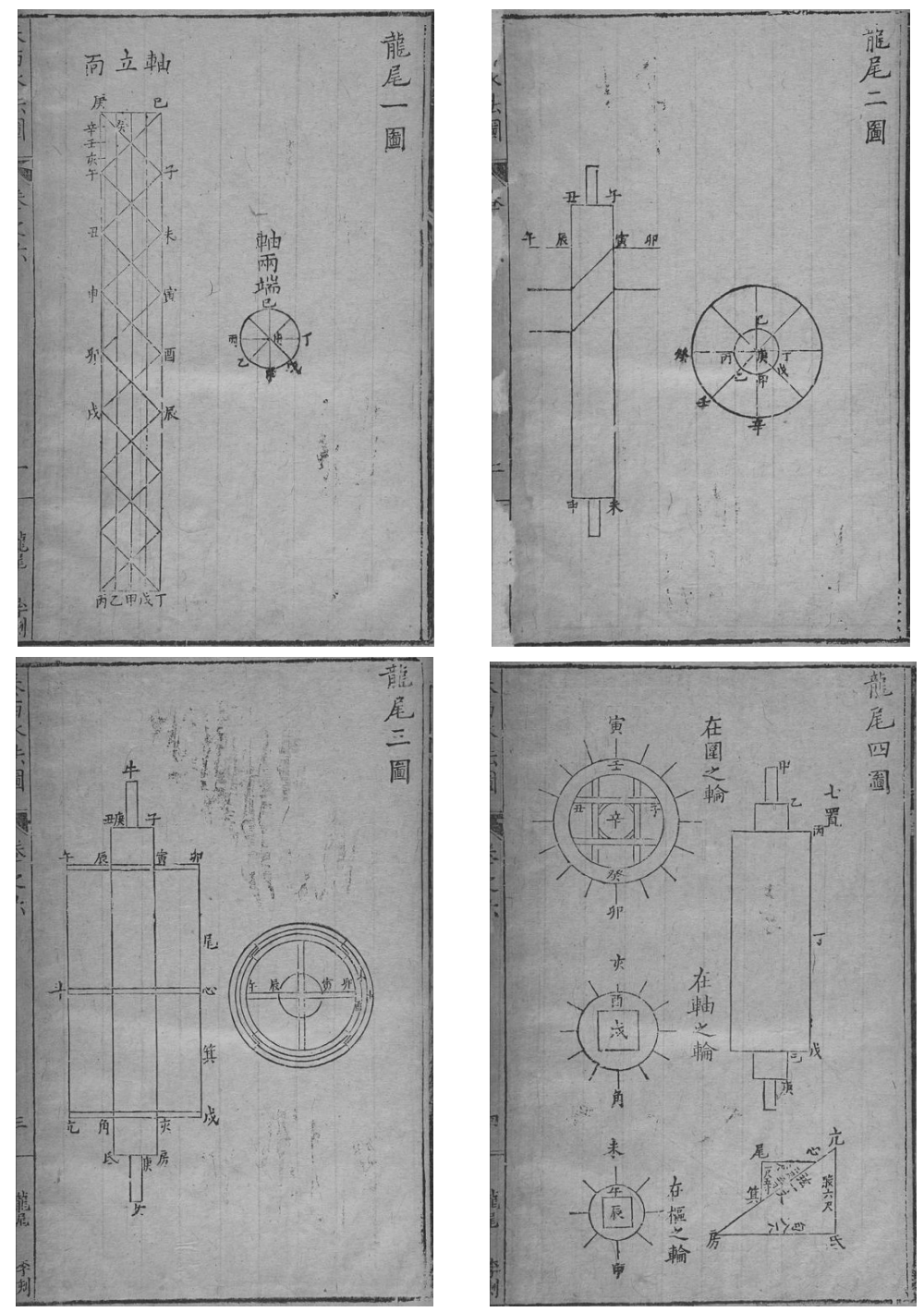

Figure 10: Detailed construction drawings of the Archimedean screw pump (Ursis and $\mathrm{Xu} 1612)$.

Besides pumps, Hydraulic Methods of the Far West introduces cisterns and reservoirs. It also discusses healing with water and introduces the concept of distillation of medicinal extracts from plants for the first time in China. An important chapter deals with the Western four-element theory of Aristotle to explain the various phenomena of 
water on earth, in contrast to the prevailing Chinese five elements theory. Hence Hydraulic Methods of the Far West is not only a technical treatise, but also provides a philosophical foundation for the systematic treatment of the origin, importance, and utilization of water on earth (Kink 2019). For this reason, many Chinese scholars became interested in the practical and philosophical aspects of Hydraulic Methods of the Far West and discussed the potential applications (Zou 2017).

\subsection{Chronicle of Foreign Lands (Zhifang waiji 職方外紀) (1623)}

Chronicle of Foreign Lands (Zhifang waiji 職方外紀) (1623) is the first detailed text on world geography in Chinese. It was published by the Italian Jesuit Giulio Aleni, SJ 艾儒 略 (1582-1649), in China since 1613, together with Yang Tingyun 楊廷筷 (1557-1627), a Chinese official and prominent early convert. Aleni completed the book based on a draft of his deceased predecessors Diego de Pantoja, SJ 龐迪我 (1571-1618) and Sabatino de Ursis and added new information that he had brought from the West. Interestingly, in this book Aleni briefly introduced and described several famous Western hydrotechnical engineering works, namely (i) the water-lifting machine of Toledo (often called Artificio de Juanelo after its creator Juanelo Turriano [1501-1585]), (ii) the aqueduct of Segovia, (iii) the fountains and water plays of a Renaissance garden (Palazzo Quirinale in Rome or Villa d'Este in Tivoli), (iv) the aqueducts of Rome, (v and vi) the water cities of Venice and Tenochtitlán Mexico, and (vii) the Archimedean screw pump. The chosen examples were intended to demonstrate Western inventiveness and ingenuity for practical application, based on sound mathematical and scientific principles. Further details about some of these works can be found in Koenig (2015).

Regarding the Archimedean screw pump, the passage in the section on Egypt, Africa, reads as follows:

There was once a king who sought a method to combat droughts and waterlogging. He found a wise and ingenious man, named Ya'erjimode [Archimedes] to make a hydraulic device, which could at the same time supply and remove water, providing people with incomparable benefits [for irrigation]. It is now named longweiche [dragontail machine $=$ Archimedean screw pump].7 (Aleni and Yang 1623, 85)

Aleni was thus the first one to introduce the name of Archimedes in China using the Chinese transliteration of Ya'erjimode 亞爾幾默得. Instead of providing technical details or an illustration of the screw pump, he told the brief story of its invention by Archimedes at the time of his visit to Egypt, without referring to Hydraulic Methods of

7 “昔有國王專求救旱澇之法, 得一智巧士曰亞爾幾默得者, 爲作一水器以時注洩, 便利無比, 即 今龍尾車也。” 
the Far West at all. In connection with his own description of the Archimedean screw pump, Gerolamo Cardano also cited the Egyptian story of Diodorus in De subtilitate (1554). However, no documented proof exists that Archimedes ever visited Egypt or invented the screw pump, but it has been a common tradition since Roman times. Hence Aleni may have told this beautiful story by Diodorus based on Cardano, even though Cardano's book was not available to him in Peking. Consequently, Aleni put the description of the Archimedean screw pump in the section on Egypt, Africa, and not in the section on Italy, Europe. Aleni's passage about the Archimedean screw was almost verbatim repeated by P. Ferdinand Verbiest, SJ 南懷仁 (1623-1688) in his Illustrations and Descriptions of the World (Kunyu tushuo 坤輿圖說) (1674).

\subsection{A Record of the Best Illustrations and Descriptions of Extraordinary Devices of the Far West (Yuanxi qiqi tushuo lu zui 遠西奇器圖說錄最, often abridged as Qiqi tushuo) (1628)}

A Record of the Best Illustrations and Descriptions of Extraordinary Devices of the Far West (Yuanxi qiqi tushuo lu zui 遠西奇器圖說錄最, often abridged as Illustrations and Descriptions of Extraordinary Devices [Qiqi tushuo]) was the first Chinese book introducing systematically European mechanics and machines to China and remained so until the mid-nineteenth century. It was published in 1628 by the lowranking scholar-official, engineer, and prominent convert Wang Zheng 王徵 (15711644), together with the German Jesuit Johann Schreck, SJ 鄧玉函 (1576-1630), who had arrived in China in 1621. Wang had read about the Artificio de Juanelo and Archimedes in Aleni's Chronicle of Foreign Lands and became interested in Western machines, particularly the Artificio, which was an ingenious system capable of delivering water from the river Tagus to the city of Toledo, overcoming a difference of more than $100 \mathrm{~m}$ in altitude. Wang went to visit the Jesuit residence in Peking where Schreck showed him various illustrated machinery books. He then persuaded Schreck to translate a work entirely devoted to this subject. As a result, a book on mechanics and instruments in three chapters (juan), called Illustrations and Descriptions of Extraordinary Devices was published in 1628 (Engelfriet 1998, 338-341). Though the emphasis was on mechanical engineering, this work also included many illustrations of hydraulic machinery (even when non-functional). Archimedean screw pumps were shown in three different arrangements, all obviously copied from Agostino Ramelli's Le diverse et artificiose machine . . . (1588) as seen for example in Figures 11.1-11.2. Noticeably, Illustrations and Descriptions of Extraordinary Devices makes a reference to Hydraulic Methods of the Far West by stating that manufacturing instructions for the Archimedean screw pump are found in Hydraulic Methods of the Far West. 
Ramelli's book was brought by Schreck to China and held in the Jesuit library in Peking (Verhaeren 1949). Recently, Illustrations and Descriptions of Extraordinary Devices has attracted much attention from scholars in China and in the West who study the Jesuit role in the development of Chinese mechanical knowledge (Walravens 2016). Particulars about Wang Zheng can be found in the interesting biography by Zhang and Tian (2009).

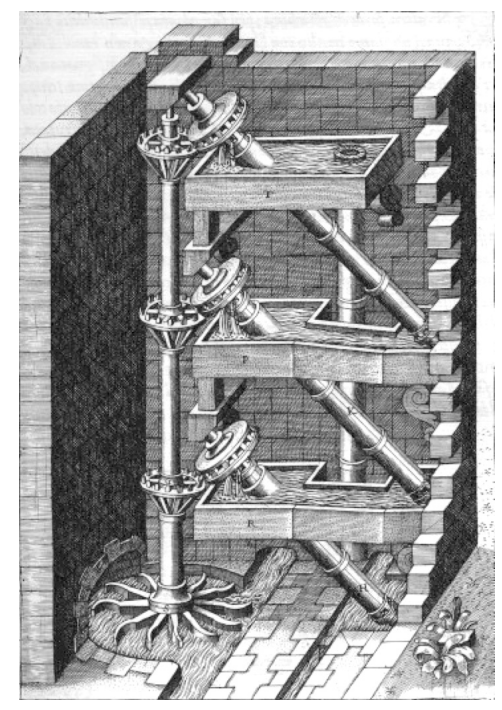

Figure 11.1: Triple Archimedean screw in Le diverse et artificiose machine... (Ramelli 1588).

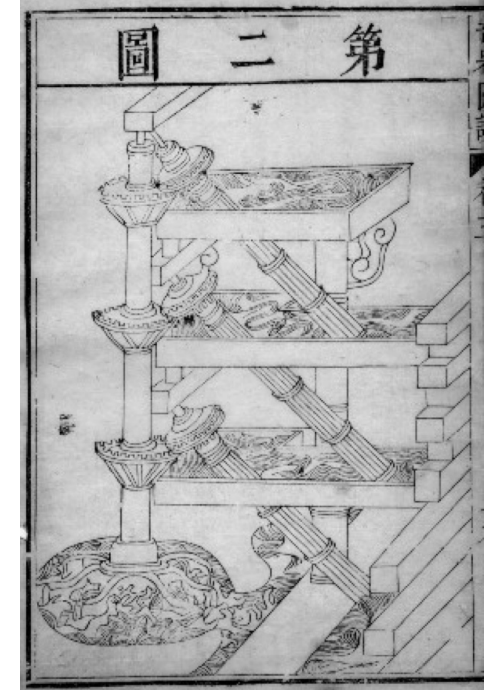

Figure 11.2: Triple Archimedean screw in Illustrations and Descriptions of Extraordinary Devices (Schreck and Wang [1628] 1830).

\subsection{Impact and applications in China}

Despite the fact that comprehensive information about the Archimedean screw pump was made available in China, it exerted only limited influence. The literature reports relatively few references concerning the screw pump, and even fewer cases of building it. It is known that Ursis and Wang Zheng built the first prototypes of the screw pump. Zhang and Tian (2010) enumerate a few more cases and provide references, based on thorough investigations conducted by the Group for History of Science and Technology at Tsinghua University Library (1983). The following builders all used the construction drawings in Hydraulic Methods of the Far West (Table 4).

Between 1756 and 1760 the French Jesuit Michel Benoist, SJ 蔣友仁 (1715-1774) is said to have installed a series of Archimedean pumps for the water plays in the European Mansions (Xiyanglou 西洋樓) of the old Summer Palace (Yuanmingyuan 圓 明園) near Peking (Xie 2006, 45); however, no documentary proof was presented.

Several scholars and officials praised the benefits of the Archimedean screw and advocated its application in agriculture or water conservancy work (Table 5). 
Table 4: Builders using the construction drawings in Hydraulic Methods of the Far West

1691 Huang Fuzhuang 黄履莊 as reported by Zhang Chao 張潮 (ca. 1650-1707).

$1809 \mathrm{Xu}$ Chaojun 徐朝俊 (1752-1823), a Shanghai astronomer and clockmaker, a fifth-generation descendant of Xu Guangqi.

1832 Qi Yanhuai 齊彥槐 (1774-1841), astronomer and magistrate of Suzhou, 1809 jinshi.

1836 Zheng Guangzu 鄭光祖 (1775-before 1844), literatus in Changshu County (The screw “was so large it needed one hundred people to carry it" and cost a lot.)

1838 Shen Xia'ou 沈狎鷗 as reported by Qian Yong 錢泳 (1759-1844), a literatus, intellectual, poet, compiler, painter, calligrapher, writer.

1869 Liu Chengzhong 劉成忠 (1818-1884), scholar-official, magistrate, 1852 jinshi, builder of eight screws, father of Liu E 劉鶚 (1857-1909) (Kwong 2001, 360-392).

Table 5: Scholars and officials praising the benefits of the Archimedean screw and advocating its application in agriculture or water conservancy work

1670s Nalan Xingde 納蘭性德 (1655-1685), Manchu aristocrat, poet, official, 1676 jinshi; mentions pump in Miscellaneous News from Lushui Pavilion (Lushuiting zashi 淥水亭雜識), juan 24.

1742 Dai Zhen 戴震 (1724-1777), scholar, philosopher, one of the compilers of Complete Collection in Four Treasuries (Siku quanshu 四庫全書), 1762 juren; in “Luoxuancheji” 螺旋車記 (1742) describes construction of Archimedean screw using the name "luoxuanche" 螺旋車.

1799 Ruan Yuan 阮元 (1764-1849), scholar-official, many appointments including viceroy of Liangguang, 1789 jinshi; wrote a biography of Sabatino de Ursis 熊三拔 in Biographies of Astronomers and Mathematicians (Chouren zhuan 疇人傳) with a short evaluation of Hydraulic Methods of the Far West (Zou 2017).

1824 Wu Bangqing 吳邦慶 (1766-1848), scholar-official, director-general of Yellow River Conservancy (East), 1796 jinshi; references pump in Essential Records for Hydraulic Agriculture (Zenong yaolu 澤農要錄) (1824).

1832 Lin Zexu 林則徐 (1785-1850), official, governor, director-general of Yellow River Conservancy (East), governor-general, 1811 jinshi; mentions pump in Opinions about Jifu's Water Conservancy (Jifu shuiliyi 畿輔水利 議) (1876).

In addition, Hydraulic Methods of the Far West was partly or fully reprinted in the following works (Table 6):

Table 6: Works partly or fully reprinting Hydraulic Methods of the Far West

1621 Treatise on Armament Technology (Wubei zhi 武備志), vol. 58, by Mao Yuanyi 茅元儀 (1594-1640?).

1626 First Collectanea of Heavenly Studies (Tianxue chuhan 天學初函), vol. 3, edited by Li Zhizao 李之藻 (1565-1630).

1639 Complete Treatise on Agricultural Administration (Nongzheng quanshu 農政全書), by Xu Guangqi.

1664 Towards a Thorough Understanding of Calendrical Science: Applications (Lixue huitong: Zhiyong 曆學會通 • 致用), by

Xue Fengzuo 薛鳳祚 (1600-1680); included a section on hydraulics with illustrations of Archimedean screws copied from Hydraulic Methods of the Far West and Illustrations and Descriptions of Extraordinary Devices.

1742 Compendium of Works and Days (Shoushi tongkao 授時通考), compiled under Emperor Qianlong (1736-1795).

1781-1782 Complete Collection in Four Treasuries (Siku quanshu 四庫全書), the great encyclopedia compiled under Emperor Qianlong.

1830 complete reprint

1844 in The Collectanea of the Mountain-Watching Pavilion (Shoushange congshu 守山閣叢書).

Like Hydraulic Methods of the Far West, Chronicle of Foreign Lands was also reprinted in First Collectanea of Heavenly Studies, Complete Collection in Four Treasuries, and The Collectanea of the Mountain-Watching Pavilion; in addition, from 1808 onwards it was included in Golden Vase in a Sea of Ink (Mohai jinhu 墨海金彀). Illustrations and 
Descriptions of Extraordinary Devices was included in Comprehensive Corpus of Illustrations and Books from Ancient Times to the Present (Gujin tushu jicheng 古今圖書集成) (17241726), the great encyclopedia compiled under Emperor Kangxi (1662-1722), and again in Complete Collection in Four Treasuries and The Collectanea of the Mountain-Watching Pavilion. In 1830 a new reprint was published. The frequent citations, reprints and inclusions in imperial encyclopedias signify the importance attached to Hydraulic Methods of the Far West, Chronicle of Foreign Lands, and Illustrations and Descriptions of Extraordinary Devices by various scholars and the government. However, because these books dealt largely with knowledge of machines and countries outside China, they never acquired a high status in the eyes of officials who preferred books on traditional morals and philosophy.

\section{Archimedean screw pumps in Korea}

Since Korea was a tributary kingdom of the Chinese empire, its government frequently sent tributary delegations to Peking. The delegations were usually headed by highranking officials with excellent knowledge of the written Chinese language, which also functioned as the official language of government and scholars in Korea. During the lengthy journey to Peking, they closely observed Chinese practices in the towns and cities they passed. Once in Peking, delegation members availed themselves of the opportunity to collect books and information on the latest developments in China, which they described in lengthy reports upon their return to Korea. Sometimes the more adventurous members visited the Jesuit residence, eager to learn about the latest calendar making methods and other Western novelties. Thus the tributary missions could serve as an ideal vehicle to transfer new Chinese and Western knowledge to Korea. Since Korea, like China, was an agricultural society, some official reports or private diaries by delegation members reported on useful agricultural technologies such as new water lifting devices for irrigation. In this context, the Archimedean screw was mentioned several times by Korean scholarofficials. Examples are enumerated in Table 7.

Another Korean scholar Ch'oe Han-gi 崔漢綺 (1803-1877) published, under slightly different names, abridged versions of Hydraulic Methods of the

Far West and Illustrations and Descriptions of

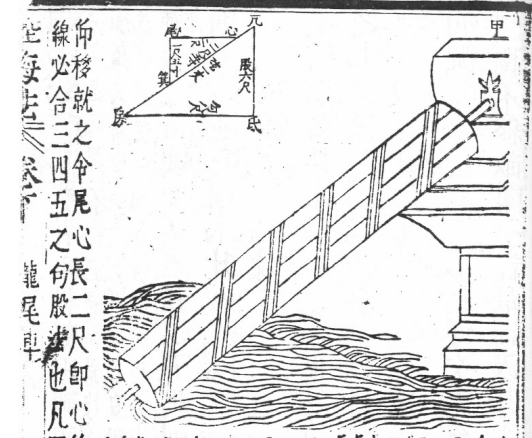

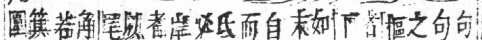

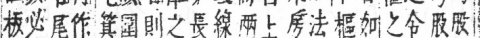

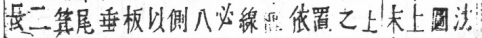

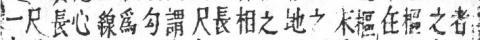

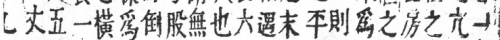

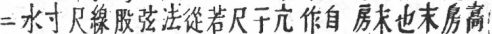

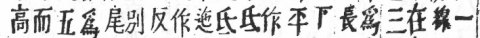

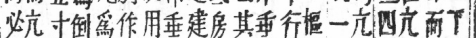

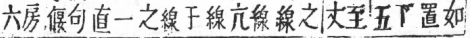

Figure 12: Archimedean screw in Techniques of Hydraulics (Yukhaebŏp 陸 海法) (Ch'oe [1834] 1981). 
Extraordinary Devices in 1834 and 1842, respectively. These books were published in the Chinese language, which functioned as the official language of government and scholars in Korea as stated above. Figures 12 and 13.1-13.2 demonstrate very clearly that the Korean version copied the illustrations from the Chinese originals (see Figure 9.2), without any modifications. The Chinese texts were also widely copied by Ch'oe. It should be noted that only a tiny minority of scholar-officials could read such books, but in view of the difficulty to obtain books from China, there was always a demand for "reprints" to disseminate advanced Chinese knowledge in Korea. Like in China, scholar-officials tended to value texts on morality and philosophy more highly than texts regarding new technologies. For this reason, it is unsurprising that no record of the construction of the Archimedean screw in Korea exists.

Table 7: Korean scholar-officials mentioning the Archimedean screw

1760 Yi Ik 李瀷 (1681-1763), scholar; wrote in Sŏngho sasŏl 星湖僿說 about the benefits of the Western "dragon tail" water lift [=Archimedean screw pump] for irrigation (Yi 1976).

1783 Seo Hosu 徐浩修 (1736-1799), scholar and diplomat; suggested King Chŏngjo (Jeongjo) (1776-1800) adopt the Yongmi-cha (Archimedean screw) (see Korean Minjok Leadership Academy 2013); visited China in 1776 and later in 1790 to congratulate Emperor Qianlong on his eightieth birthday (see his Journey to Jehol [Rehe jiyou 熱 河紀遊]; Seo [1790] 2013).

1790s Pak Jiwon 朴趾源 (1737-1805), philosopher, writer, bureaucrat; accompanied the Royal Envoy in 1780 to congratulate Emperor Qianlong on his seventieth birthday; wrote in the Jehol Diary (Rehe riji 熱河日記) about the Archimedean screw pump and mentioned Illustrations and Descriptions of Extraordinary Devices and Complete Treatise on Agricultural Administration, as well as other books on technology (Pak [1792] 2010).

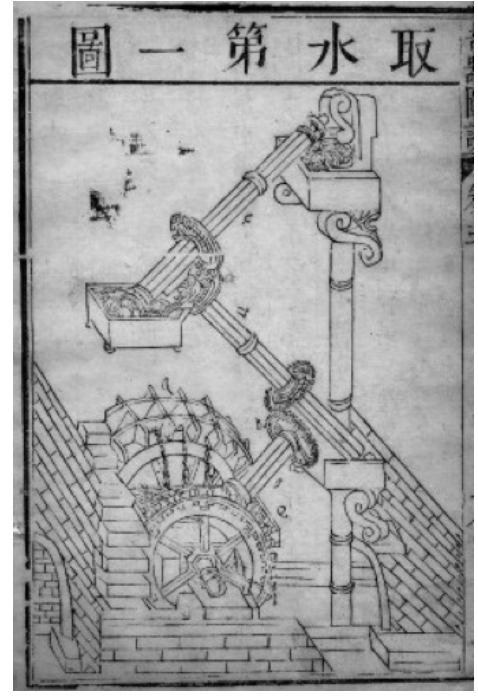

Figure 13.1: Archimedean screw in Illustrations and Descriptions of Extraordinary Devices (Schreck and Wang [1628] 1830).

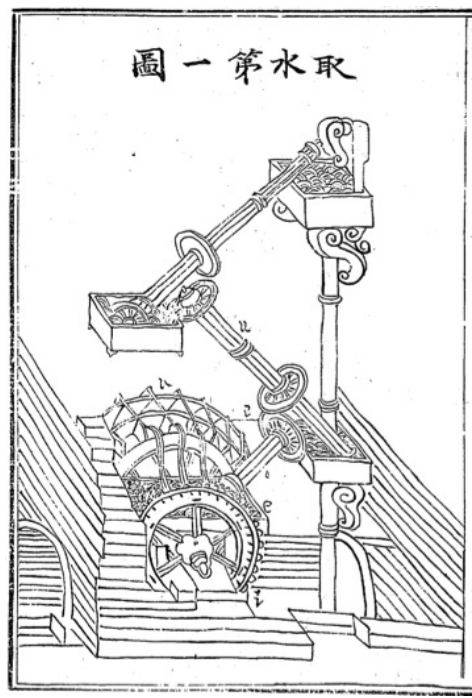

Figure 13.2: Archimedean screw in Illustrations and Explanations of Important Machines (Simgi tosŏl 心器圖說) (Ch'oe [1834] 1981). 


\section{Archimedean screw pumps in Japan}

From around 1635 until 1853 Japan followed an isolationist policy of national seclusion, which is called the Edo period. In addition, from 1630 until 1720 the import of twenty Chinese books by Christian-Jesuit authors was specifically prohibited, including Hydraulic Methods of the Far West, Chronicle of Foreign Lands, and Illustrations and Descriptions of Extraordinary Devices. It was only after shogun Yoshimune relaxed the rules in 1720 that an influx of foreign books and their translations entered Japan. Chronicle of Foreign Lands was officially imported in 1721 and Illustrations and Descriptions of Extraordinary Devices in 1736 (Oba 1996); a complete edition of Illustrations and Descriptions of Extraordinary Devices in Japanese was printed in 1830 (Fung 2009), but no official record was found on the import of Hydraulic Methods of the Far West. However, Hydraulic Methods of the Far West was mentioned as early as 1731 in the best-selling book A Farmer's Companion (Hyakusho bukuro 百姓囊 $=$ 百姓袋 $)$ by the scholar Nishikawa Joken 西 川如見 (1648-1724) who recommended farmers to read it. In his 1789 book Bold Words of Grasses and Reeds (Sobokigen 草茅危言), the scholar Nakai Chikuzan 中 井竹山 (1730-1804) meticulously described the Archimedean screw pump using the Chinese term 龍 尾車 (read in Japanese as ryubisha) (Nakai [1789] 1915). Interestingly, he made explicit reference to the Chinese military encyclopedia Treatise on Armament Technology (Wubei zhi 武備志) (Mao [1621] 1984, juan 136) and not to Hydraulic Methods of the Far West. The comprehensive agricultural encyclopedia Illustrated Explanations of the Forms of Things (Seikei Zusetsu 成形 圖說), compiled between 1793 and 1804 by order of Lord Shimazu Shigehide 島津重豪 (1745-1833) of Satsuma Province, contains a beautiful colored illustration of an Archimedean screw in volume 12 of the thirty volumes still extant (Figure 14) (So and

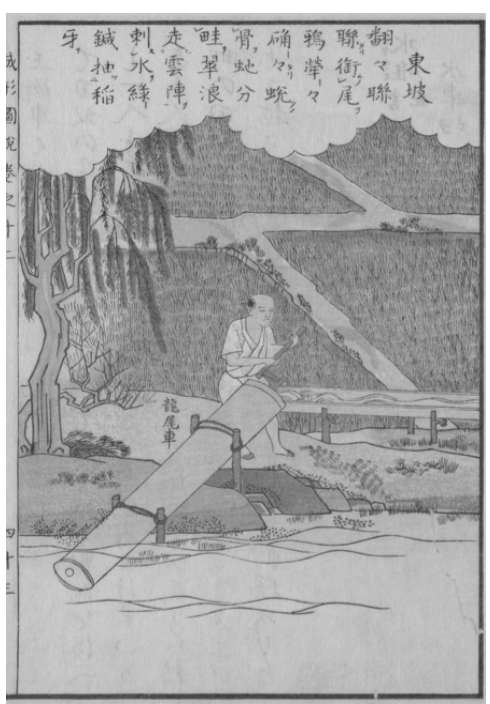

Figure 14: Archimedean screw used for irrigation (Illustrated Explanations of the Forms of Things) (So and Shirao 1804). Shirao 1804).

More detailed information about the introduction and historical application of the Archimedean screw in Japan can be found in Janata et al. (1972) and Maeda (1983). Janata et al. (1972) relate that the Records of the Peasant (Hyakusho denki 百姓伝記), written by an unknown author as early as in the 1680s, mentions an irrigation device named suishorin (in Japanese script). Based on its description, they believe it refers to an Archimedean screw but found no evidence as to where or how the author might have obtained knowledge of such a device. Maeda presented two drawings of a novel wooden Archimedean screw for water conservancy, called a water suction pipe 
(kyusuito 吸水筒) (Figure 15). They were included, together with those of four other water-lifting devices, in an agricultural treatise of 1836 entitled Compilation of WaterRelated Machines (Ungeiki-san 雲霓機纂), which was edited by Tokugawa Nariaki 徳川 斉昭 (1800-1860), Lord of Mito Province and father of the last shogun Tokugawa Yoshinobu. The pictures show an ingenious octagonal design with the inner screw affixed to the outer tube. This was easier to construct than a round design, thus demonstrating the high level of craftsmanship and inventiveness of Japanese workers.

While the Archimedean screw was traditionally described in the context of agricultural applications, it came as a big surprise when Treptow (1918) published photos of Archimedean screw pumps from a picture scroll of a Japanese gold mine on Sado Island (Figures 16.1-16.2). Such scrolls were unknown in the West until the late nineteenth century when foreign mining engineers, hired by the Japanese government or other early visitors, brought them back. The scroll's detailed illustrations and brief explanatory captions depicted the gold mine and its various processes, including the mine entrance, the work underground, drainage systems, ventilation systems, ore processing,

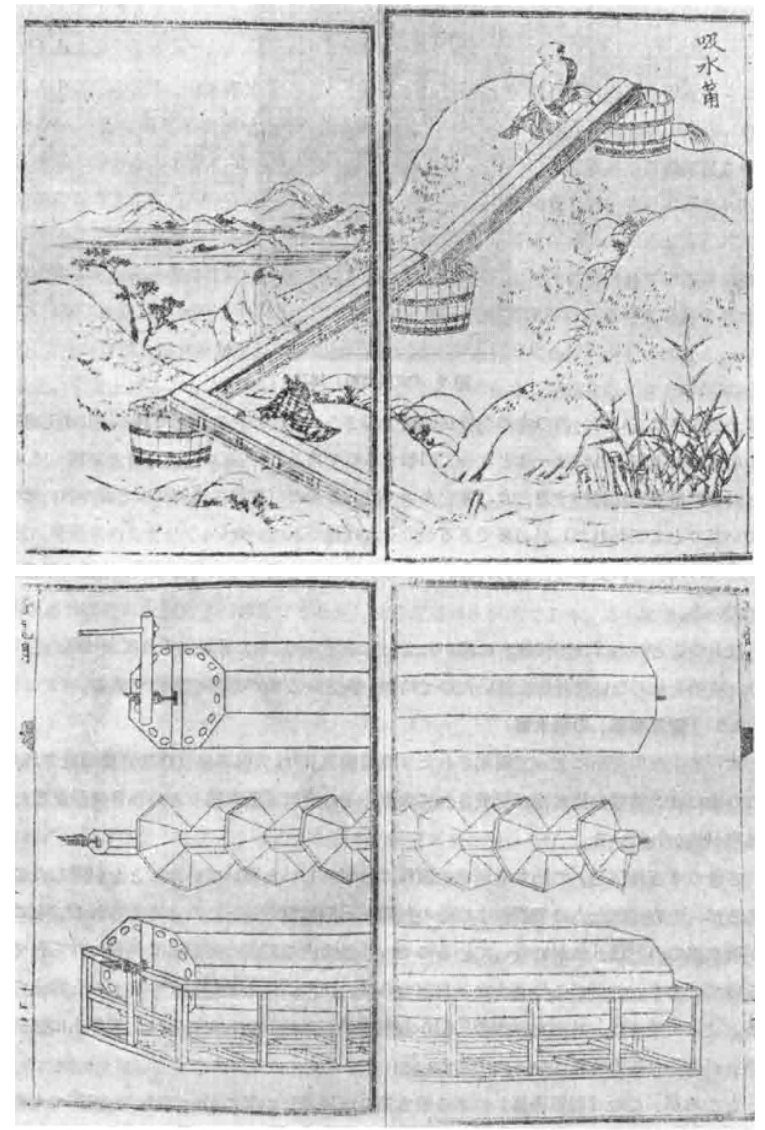

Figure 15: The Japanese water suction cylinder 吸水筒 (above: application; below: schematic drawing) (Maeda 1983). 
and the sale of the final product. Scrolls were up to $20 \mathrm{~m}$ long, about $25 \mathrm{~cm}$ wide, hand colored, and of great interest, especially to mining historians. The scrolls are generally not dated but originated between the 1730s and 1850s; the artists remained mostly anonymous. Mathias (2013) gives a good overview of the history and significance of the mining scrolls. She reports that as of October 2009 Japanese researchers had gathered more than a hundred Sado scrolls from all over Japan. Outside Japan, I have so far found thirty-three Sado scrolls in publications and websites, including two by a bookseller. Of these, eleven depicted Archimedean screw pumps used for drainage, six showed no illustrations of them, and the rest remained unknown (see Appendix 2). Of the eleven illustrations, five showed single screws (all in placer deposits), one showed a double screw in series, and five showed a triple screw in series (Figures 16.1-16.2 and 17.1-17.2). In Japan, Sugimoto and Swain (1978, 187) reported even to have found an example of a septuple screw (Figures 17.1-17.2).
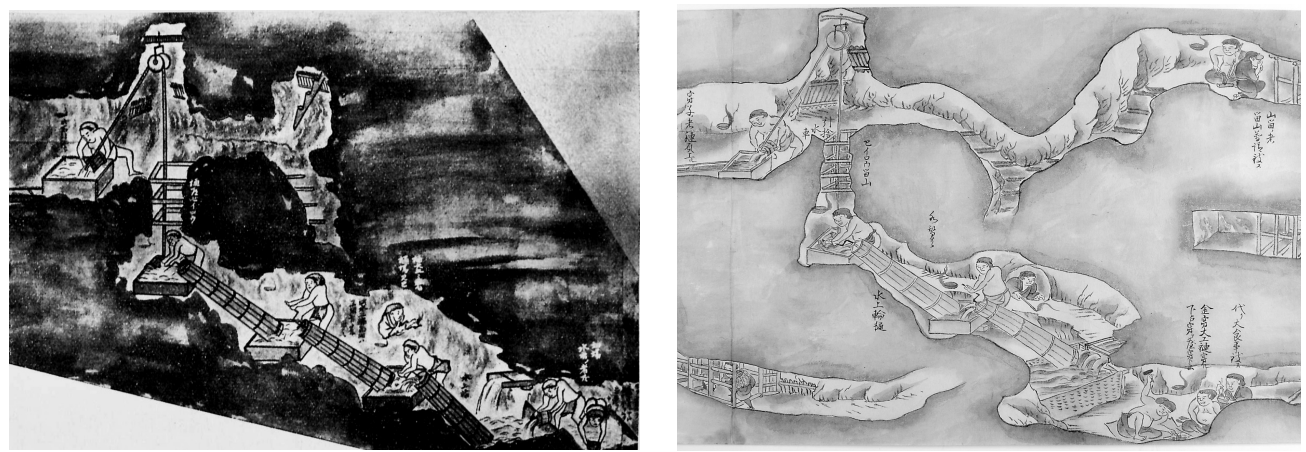

Sado Island Gold Mining Scroll

Figure 16.1: Triple Archimedean screw (Treptow 1918).

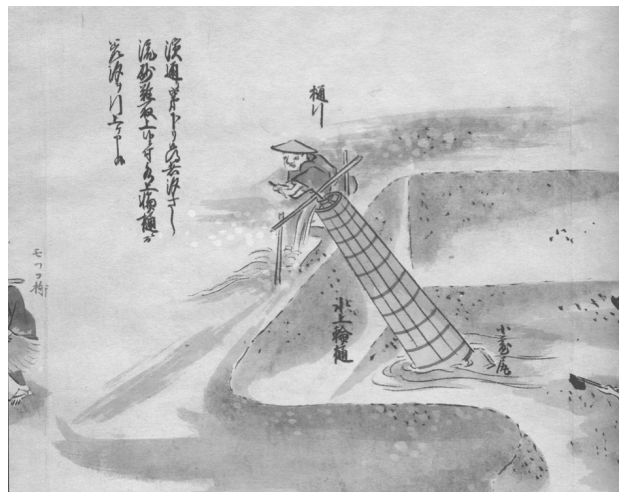

Sado Island Gold Mining Scroll
Figure 16.2: Double Archimedean screw (Courtesy of Stadt- und Bergbaumuseum Freiberg, Germany).

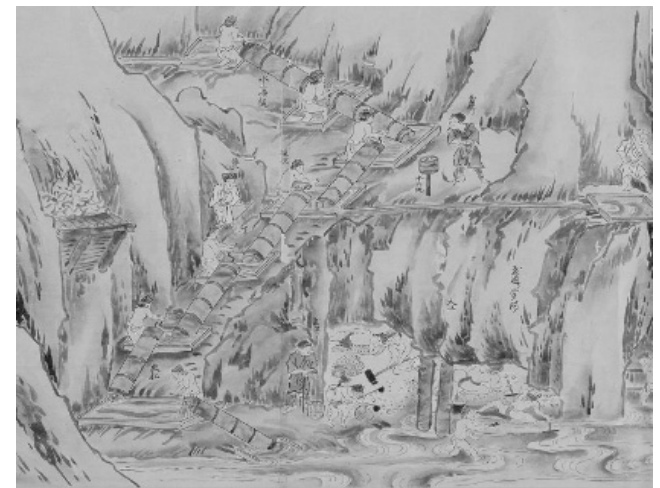

Figure 17.2: Septuple Archimedean screw (Courtesy of National Archives of Japan Digital Archive $\left.{ }^{8}\right)$.

8 https://www.digital.archives.go.jp/das/image-l/F1000000000000031992. 
Most illustrations follow a similar pattern, implying a general kind of master scroll, with individual variations depending on artist, year, scope, intended receiver, and so forth. Distinction between originals and copies is difficult. Using the single Archimedean screw pump in placer gold mines as an example, Figures 18.1-18.2 demonstrate clearly the similarity of the illustrations in two different scrolls. As in many other comparable scrolls (see also Figure 17.1), the shape of the pits as well as the number and positions of the workers are almost identical. Only some colors, the positioning of the text, and the number of rings around the outer cylinder of the screw vary. Similar observations can be made regarding the illustrations of the triple Archimedean screw pump as seen in Figures 19.1-19.2 (see also Figure 16.1).
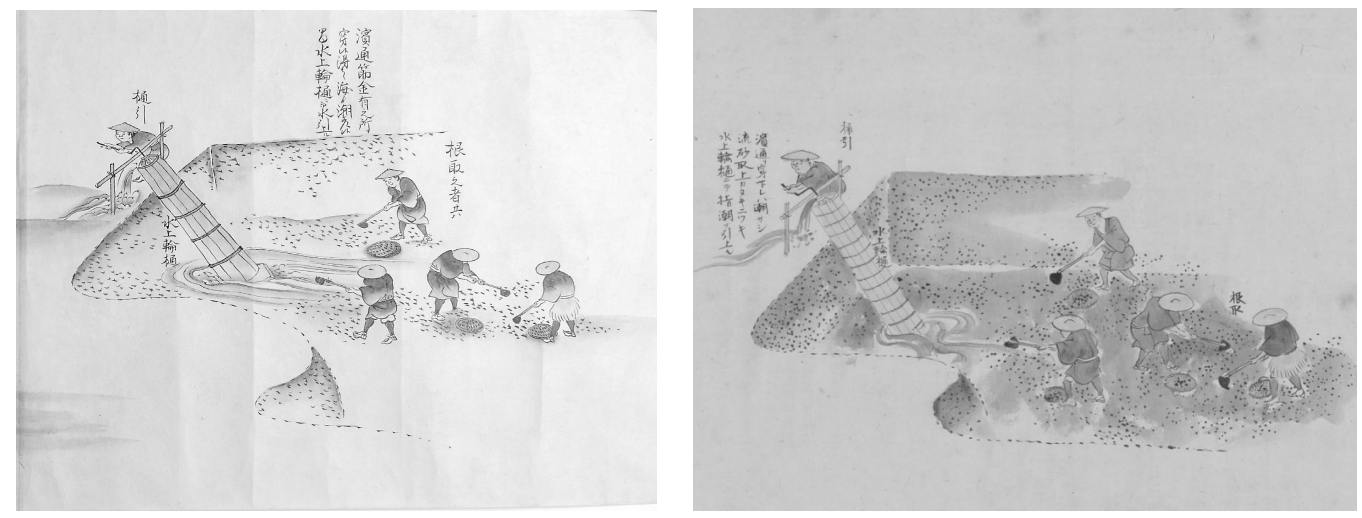

Sado Island Gold Mining Scroll with Archimedean screw pump used in a placer deposit

Figure 18.1: Courtesy of Stadt- und Bergbaumuseum Freiberg, Germany, ca. 1839.

Figure 18.2: Oka, Motojí dit Oka, Tōen. ca. 1885-1895, courtesy of Mines ParisTech.
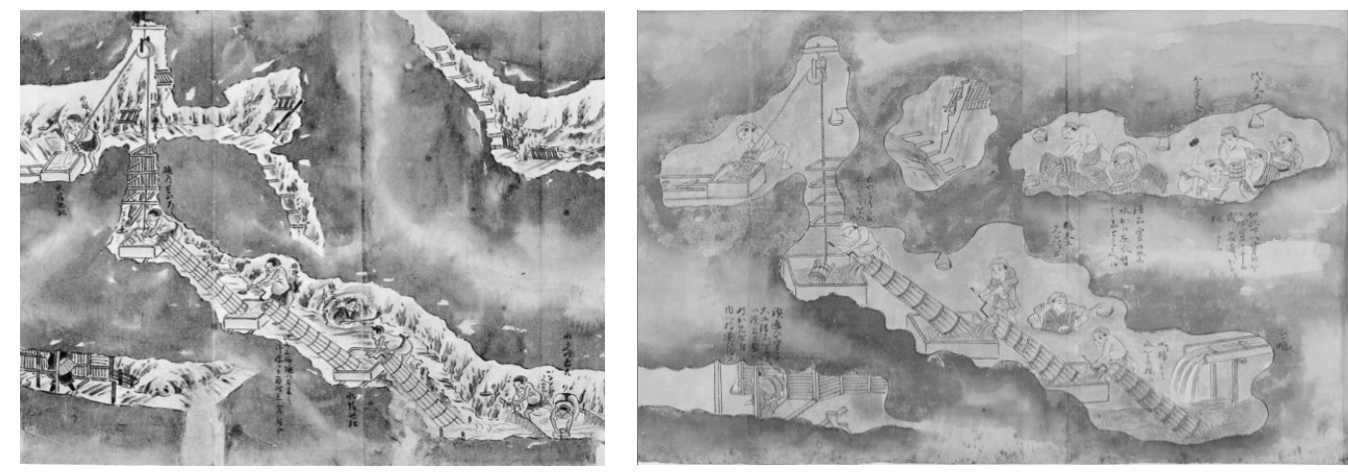

Sado Island Gold Mining Scroll with illustrations of triple Archimedean screw pumps

Figure 19.1: Courtesy of Niigata

University Library, Japan.
Figure 19.2: Courtesy of Staatsbibliothek zu Berlin [Berlin State Library $]^{9}$.

9 https://digital.staatsbibliothek-berlin.de/werkansicht?PPN=PPN168879820X\&PHYSID= PHYS_0001. 
So how did the Archimedean screw get to Japan? Nagase-Reimer (2013) writes: “In 1637 a wooden Archimedean screw called water raising wheel (suishorin 水上輪) was first used in the Sado mines. Suigako Soho 水学宗甫, a blind scholar who had studied this technique in Nagasaki, had been invited from Osaka to come to Sado to build the device on site" (see also Sado-gun Kyōikukai [1637] 1935). Elsewhere, Todd (1998) gives 1618 as the year of first application of the screw; the Aikawa Folk Museum claims the year to be 1653 . At one time 200 to 300 Archimedean screws with hand cranks were employed in the Sado mines (Nagase-Reimer 2013). Nagase-Reimer writes further: "It is probable that the technique of the Archimedean screw was brought from China to Japan. Hydraulic Methods of the Far West contains a description of the Archimedean screw. . . . It would appear that Suigaku obtained and studied the book prior to 1630, or that copies circulated clandestinely even during the period of the prohibition." However, according to Maeda (1983) knowledge of the Archimedean screw could also have reached Japan via the Chinese military encyclopedia Treatise on Armament Technology (Mao [1621] 1984) of 1621, which included the complete description and drawings of Hydraulic Methods of the Far West in the section on water conservancy for military settlements (refer to Figure 10). Besides, its import to Japan was not restricted during the period of banning Western Christian books. It is interesting to note that the term suishorin was also used in Hyakusho denki (1680s), but has no precedents in China.

When the first foreign mining engineers arrived in Japan after the end of the Edo period in the 1850s, they did not encounter Archimedean screws for mine drainage any more. They had been replaced by simpler, yet more reliable methods like wooden hand pumps (Netto 1879). But remains of ancient screws are preserved today in the Aikawa Folk Museum on Sado Island and in other museums (Maeda 1983; NagaseReimer 2013). In addition, the Aikawa Folk Museum exhibits working drawings of Archimedean screws for use in the gold mines (Maeda 1983; Nagase-Reimer 2013). The drawings went on display in 1979, shortly after their discovery. A sample of such drawings is shown in Figure 20. There is a striking resemblance between the Japanese screws and those in Hydraulic Methods of the Far West in terms of shape, length, diameter, and inclination, thus strongly suggesting a design based on Hydraulic Methods of the Far West and ultimately on Vitruvius (see also Cigola and Fang 2016). The main difference seems to be that the Japanese screws have a slightly larger diameter at the inlet than at the outlet as also seen in the picture scrolls. Disregarding the somewhat improbable story of blind Suigaku, Japan, instead of China, turned out to be the true beneficiary of this particular West-East knowledge transfer of the Archimedean screw. 


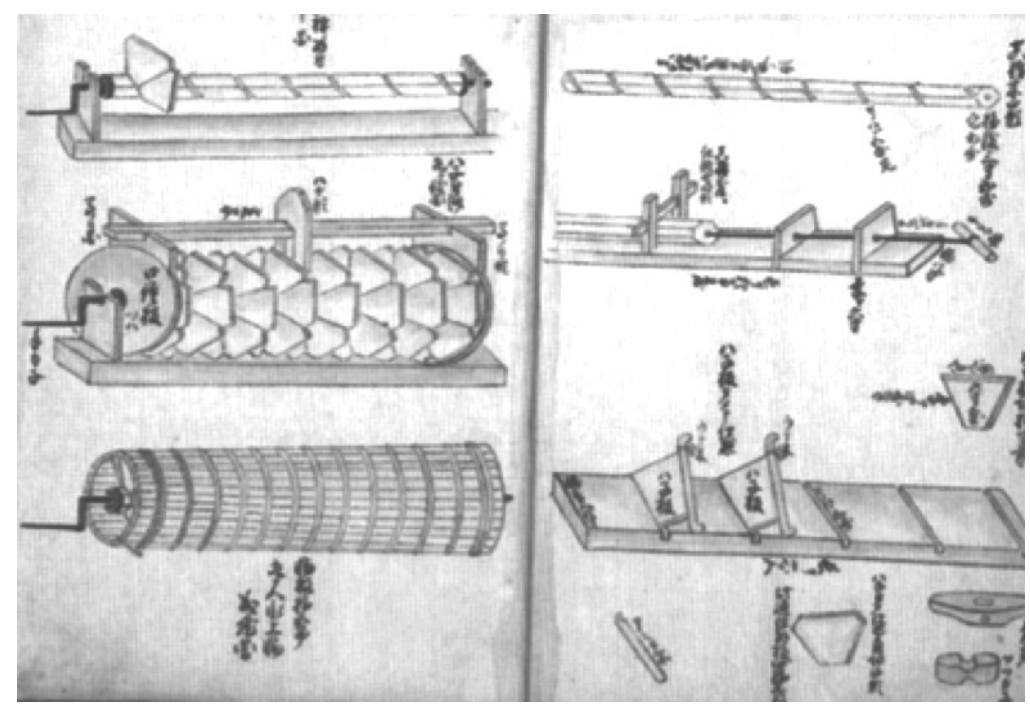

Figure 20: Ancient working drawings of the Archimedean screw in the Aikawa Folk Museum (Maeda 1983; Nagase-Reimer 2013).

\section{Discussion}

One may ask why Sabatino de Ursis chose the Archimedean screw pump at all for introduction to China, since even in Europe it was only rarely utilized. Was it because of the perceived need for irrigation in the immense paddy field areas of China, where the screw pump was deemed to be the most efficient water raising device? Even Qi Yanhuai believed that the screw pump was equivalent to five traditional square-palletpumps (Zhang and Tian 2010). Or was the reason simply the novelty of the device that hitherto was not known in China? Despite the supposed need for the more efficient method provided by the Archimedean screw pump, it was actually seldom used in practice. Many impediments could be adduced: (i) insufficient dissemination of information among its potential users; (ii) delicate mechanism and lack of suitable craftsmen for manufacture; (iii) lack of understanding of the screw's theoretical principle, then still unknown in China; (iv) heavy weight and high production cost; (v) difficulty of repair; (vi) impractical Vitruvian design (already noted by Ceredi and Liu Chengzhong) and vague construction drawings; (vii) preference by farmers for simpler, cheaper, lighter, more mobile, and more functional water-lifting devices like the square-pallet chain pump; (vii) unsuitable social structure, such as too few officials for the masses of small farmers with tiny plots; (viii) inadequate cost-benefit ratio for chosen application and scale.

Regarding the dimensions of the Archimedean screw pump, an important point was recently raised by Kink (2019): Whereas Vitruvius states that "the total diameter [of the pump] is equal to one eighth of the length" (see section 3 of the English translation in 
the Appendix), Hydraulic Methods of the Far West says that the ratio of 8:1 applies only to the height of its wall ("one divides the length of the shaft into eight parts and takes one part as the height of the wall. [This height] can be reduced, but not increased") (Ursis and $\mathrm{Xu}$ 1612). ${ }^{10}$ This change in the interpretation of the 8:1 ratio would result in a pump with a total length-to-total diameter ratio of about 3:1 and make it disproportionately thick as well as unsuitable for use. Interestingly, this discrepancy can also be noted in Figure 9.2, which shows a Western representation of the Vitruvius pump with a length-to-total diameter ratio of 8:1, while Figure 10 (upper left) appears to depict a pump made according to the recommendation in Hydraulic Methods of the Far West exhibiting a ratio of 3:1. However, Hydraulic Methods of the Far West makes the reservation that "in case one wants to make a 'long' shaft, then the height of the [helix] wall [should] be the same as the diameter of the shaft."11 In this case, only a diameterto-length ratio of the shaft of 24:1 would result in the Vitruvian length-to-total diameter ratio of 8:1. Cigola and Fang (2016) pointed to another discrepancy with the Vitruvius text. Subsection 1 of the Chinese text mentions "a length-to-diameter ratio for the shaft of 25:2,"12 but the English translation (section 1) based on the Latin text states clearly, "A beam is selected, the thickness of which in digits is equivalent to its length in feet." According to the ancient Roman units of length, one digit equals 1/16 of a foot, therefore the correct ratio should be 16:1 instead of 25:2. In the seventeenth and eighteenth century, the same foot-to-digit ratio of 16:1 was still used in Rome, as Sabatino de Ursis was studying at the Collegio Romano. If, according to Vitruvius, the length-to-diameter ratio of the shaft is $16: 1$ and the length-to-diameter ratio of the pump is $8: 1$, then the height of its wall would be equal to the radius of the shaft, in essence the diameter of the shaft equals one half the total diameter of the pump. The illustration in the English translation shows exactly this relationship. Further investigation might be required as to why Sabatino de Ursis changed the qualitative meaning of the 8:1 ratio in the former case and the quantitative value of the length-todiameter ratio in the latter case when compared to the original Vitruvius text. It is not clear whether we are dealing with an error in interpretation, an error in translation, or a deliberate modification of Vitruvius's text. In any case, the dimensions of the Archimedean screw pump in China varied from the Vitruvius model. At the same time, it should be noted that the dimensions of some excavated Archimedean screw pumps from Roman times also deviated from Vitruvius's recommendations. Apparently, the Romans were flexible enough to modify the design according to local circumstances. In addition, Kink (2019) noted that Ursis suggested several possibilities of driving mechanisms besides the simple hand-operated crank-namely animal power, wind

10 “八分其軸長, 以其一爲墙之高。可减也, 不可加也。”

11 “若欲爲長軸, 則墻之高, 與軸之徑等。”

12 “二十五分其軸之長, 以其二爲之徑。” 
power, or water power ${ }^{13}$ coupled with a simple gearing system-whereas Vitruvius claims "the screw is turned by the treading of men [only]" (subsection 3 in Latin and English). This shows that Ursis included some recent advances made in machine science during the Renaissance, quite unlike the contemporary Western editions and translations of Vitruvius. Water-powered Archimedean screw pumps are only depicted in the manuscripts by Gruter ([1424] 2006), Francesco di Giorgio (ca. 1484), ${ }^{14}$ Taqi alDin (1551), and Francisco Lobato del Campo (García Tapia and García-Diego [ca. 1585] 1987), and Pseudo-Juanelo (ca. 1595), as well as in the machinery books by Errard (1584) and Ramelli (1588); however, none of these were available to Ursis with the exception of Ramelli. Animal and wind power had not been mentioned in the Western literature up to this point. Hence it can be said that the Archimedean screw pump in Hydraulic Methods of the Far West represented a modern, original approach and thus an improvement over the classical device. ${ }^{15}$

Perhaps in China the Archimedean screw was considered more an interesting curiosity than a true improvement over traditional designs that were actually not that inferior to the Archimedean screw (Zhang and Tian 2010; Su and Shi 2017). Davids (2006) posed the question of why Western hydraulic advancements never exerted any influence in China. He suggested that the monopoly of knowledge by the imperial bureaucracy and its officials precluded any effort to develop new approaches. This claim contrasted strongly with the competitive situation in Europe with its diversity of institutions, scholars, administrators, and governments. Qiu (2005) is of the view "that whether an exotic appliance [such as the longweiche] can be accepted or not is not absolutely determined by the state of art but properties of culture ecology at that time." Zou (2017) gives a comparable reason: "In the process of interaction between Chinese and Western water culture, the spread and influence of Hydraulic Methods of the Far West became a very typical case illustrating the 'changing' and 'laggard' elements in cross-cultural knowledge communication." Furthermore, fears of disrupting the social stability of the rural population through loss of work due to foreign machines arose (Kink 2019). Similar arguments have been forwarded to explain the resistance to the introduction of other sciences and technologies to China (and for that matter to Korea);

13 “若平地受水而用人力、畜力、風力者, 當在甲乙丙矣, 用水力。”

14 For the water-powered Archimedean screw in Disegni di macchine, see https://brunelleschi. imss.fi.it/genscheda.asp?appl=LIR\&xsl=paginamanoscritto\&chiave=101326.

15 For these clarifications I am grateful to Sabine Kink, MA, who is working on a PhD thesis about the Hydraulic methods of the Far West within the DFG funded project "Translating Western Science, Technology and Medicine to Late Ming China: Convergences and Divergences in the Light of the Kunyu gezhi 坤輿格致 (Investigations of the Earth's Interior; 1640) and Taixi shuifa 泰西水法 (Hydromethods of the Great West; 1612)." This project was granted by the German Research Foundation for the years 2018 to 2021 and is carried out at the Department of Chinese Studies at Eberhard Karls University of Tübingen under the direction of Prof. Dr. Hans Ulrich Vogel. 
however, many open questions remain.

In contrast, Japan seemed to have enthusiastically accepted the Archimedean water screw, despite minimal available information. However, they used it mainly for a very specific application not even mentioned in Hydraulic Methods of the Far West, namely for drainage of mines as the Romans had done almost 2000 years ago. Here, many positive factors can be listed: (i) excellent craftsmen, (ii) openness to improvements over traditional methods, (iii) adaptability to accept new knowledge, (iv) no obstacles due to different social classes, (v) great need for more efficient drainage, (vi) continuous operation throughout the year, (vii) high cost-benefit ratio in the gold mines. Hence, despite Japan being cut off from the rest of the world, more Archimedean screws were operated there during the seventeenth century than in any other country of the world. At that time, Western mines were already using mechanical pumps because of their superiority over Archimedean pumps in terms of water lift. But at the beginning of the eighteenth century, Archimedean screws became widely applied in Europe, in particular in the Low Countries in combination with windmills to drain polders.

\section{Conclusion}

It has been shown that the Archimedean screw pump was introduced in China via three books co-written by Jesuit missionaries and their Chinese collaborators, namely Hydraulic Methods of the Far West (1612), Chronicle of Foreign Lands (1623), and Illustrations and Descriptions of Extraordinary Devices (1628). Hydraulic Methods of the Far West was the most influential because of its detailed description and construction drawings, which were based on De architectura by Vitruvius. Though highly praised by many Chinese scholars and despite many reprints of Hydraulic Methods of the Far West, the Archimedean screw pump was rarely applied to irrigation as originally intended. Knowledge about it was transferred to Korea by members of tributary delegations visiting the Imperial Court in Peking; however, it did not have any significant impact. No mention of the Archimedean screw could be found in Vietnam, despite its close cultural association with China; although it is not completely impossible that Hydraulic Methods of the Far West or any of its various reprints reached the country through Jesuit missionaries. Surprisingly, the content of Hydraulic Methods of the Far West found its way to Japan despite the rigid import controls on Jesuit books. Archimedean screw pumps were built by the hundreds to be successfully used in the drainage of gold mines in Sado Island. This was amply documented in contemporary picture scrolls of the mines, which caught the attention of Western mining engineers only at the end of the nineteenth century. Thus, contrary to the original intention of Hydraulic Methods of the Far West, the Archimedean screw proved to be more suitable for drainage than for irrigation. 


\section{Acknowledgment}

The author would like to extend his sincere gratitude to Prof. Dr. Regine Mathias for her valuable assistance in providing rare Japanese literature, information on the Sado scroll in Paris, as well as for her advice in the translation and explanation of some difficult Japanese terms.

\section{References}

Aleni, Giulio, SJ, and Yang Tingyun 楊廷筷. 1623. Zhifang waiji 職方外紀 [Chronicle of Foreign Lands]. Hangzhou. Available at https://www.wdl.org/en/item/227/.

Barbaro, Daniele. 1556. Vitruvius: I dieci libri dell'architettura di M. Vitruvio tradutti et commentati da Monsignor Barbaro eletto patriarca d'Aquileggia. Vinegia: per Francesco Marcolini.

*Barbaro, Daniele. 1567. De architectura libri decem, cum Commentariis Danielis Barbari ... Venetiis: Apud Franciscum, Franciscum Senensem \& Ioan Crugher Germanum.

*Barbaro, Daniele. 1584. I dieci libri dell'architettura di M. Vitruvio, tradotti et commentati da Monsig. Daniel Barbaro ... Venetia: Appresso Francesco de Franceschi Senese.

Bartoli, Daniello, SJ. 1663. Dell'historia della Compagnia di Giesu: La Cina, Terza parte dell'Asia. Roma: Stamperia delVarese.

Branca, Giovanni. 1629. Le machine. Roma: Iacomo Mascardi.

Bromehead, C. N. 1942. "Ancient mining processes as illustrated by a Japanese scroll." Antiquity 16 (63): 193-207.

Cardano, Gerolamo. 1554. Hieronymi Cardani Mediolanensis, Medici, De Subtilitate Libri XXI. Liber I:18-20. Basileae: per Ludovicum Lucium.

Cardano, Gerolamo. 1654. De propria vita liber. Amstelaedami: Apud Joannem Ravesteinium.

Ceccarelli, M. 2008. "Renaissance of Machines in Italy: From Brunelleschi to Galilei through Francesco di Giorgio and Leonardo." Mechanism and Machine Theory 43 (12): 1530-1542.

Ceccarelli, Marco. 2014. "Contributions of Archimedes on mechanics and design of mechanisms." Mechanism and Machine Theory 72:86-93.

Ceredi, Giuseppe. 1567. Tre discorsi sopra il modo d' alzar acque da' lvoghi bassi . . Parma: Appresso Seth Viotti. https://echo.mpiwg-berlin.mpg.de/ECHOdocuView?url=/permanent/archime des_repository/large/cered_disco_021_it_1567/index.meta\&viewMode=auto\&pn=1.

Chester Beatty Library. 2012. A scientific response to the Chester Beatty Library Collection. Dublin: Chester Beatty Library.

Ch'oe, Han-gi 崔漢綺. [1834, 1842] 1981. Nongsŏ. 13. Nongsŏ: Nongjŏng hoeyo 3, Yukhaebŏp, Simgidosŏl (農書 13. 農書: 農政會要 3, 陸海法, 心器圖說), edited by Han'gukhak-Munhŏn-Yŏn'guso. Seoul: Asea Munhwasa.

Cigola, Michela, and Marco Ceccarelli. 2014. "Marcus Vitruvius Pollio (Second Half of the 1st Century B.C.)." In Distinguished Figures in Mechanism and Machine Science: Their Contributions and Legacies, Part 3, edited by Marco Ceccarelli, 309-346. History of Mechanism and Machine Science 26. Dordrecht: Springer.

Cigola, Michela, and Fang Yibing. 2016. "Traces and echoes of De Architectura by Marcus Vitruvius Pollio in the work of Xu Guangqi in 17th century." Frontiers of Mechanical Engineering 
11 (1): 3-11.

Davids, Karel. 2006. "River control and the evolution of knowledge: a comparison between regions in China and Europe, c.1400-1850." Journal of Global History 1 (1): 59-79.

Diodorus Siculus. 1939. Library of History, Volume III, Loeb Classical Library, translated by Oldfather, C. H. Cambridge, MA: Harvard University Press. Also available at www.math.nyu. edu/ crorres/Archimedes/Screw/SourcesScrew.html.

Engelfriet, Peter M. 1998. Euclid in China: The Genesis of the First Chinese Translation of Euclid's Elements, Books I-VI (Jihe Yuanben, Beijing, 1607) and Its Reception up to 1723. Leiden: Brill.

Errard, Jean de Bar-le-Duc. 1584. Le premier livre des instruments mathematiques mechaniques. Imprimé à Nancy, par Ian-Ianson. Also available at https://gallica.bnf.fr/ark:/12148/bpt6k15 11341x.image.

FDFA. 2016. “Art and Diplomacy: Sado Island Gold and Silver Mining Scroll (2016)." In 150 years of diplomatic relations between Switzerland and Japan: Jubilee Appraisal and Reproduction of the 1864 Original Versions of the Treaty of Friendship and Commerce Switzerland-Japan. Bern: Federal Department of Foreign Affairs (FDFA).

Forbes, Robert J. 1966. Studies in Ancient Technology: Vol. VII. Leiden: Brill.

Ford, T. D., and I. J. Brown. 1995. "Early gold mining in Japan: the Sado scrolls." Bulletin of the Peak District Mines Historical Society 12 (6): 1-17.

Ford, T. D., and I. J. Brown. 1998. “Early gold mining in Japan: more Sado scrolls.” Mining History: The Bulletin of the Peak District Mines Historical Society 13 (6): 33-39.

Fung, K. W. 2009. “Riben Jianghu shiqi de liangge jieyiben” 日本江户时期的两个节译本 [Two selected Japanese translations on Qiqi tushuo in Edo Japan]. In Chuanbo yu huitong: Qiqi tushuo luzui yanjiu yu jiaozhu 传播与会通——《(远西) 奇器图说 (录最)》研究与校注 [Transmission and Integration: Qiqi tushuo (Illustrations and Descriptions of Extraordinary Devices): New Research and Annotated Edition] vol. 1:219-224. Nanjing: Phoenix Science Press.

Galilei, Galileo. 1634. Les méchaniques. Paris: Henri Guenon.

García Tapia, Nicolás, and José García-Diego, eds. [ca. 1585] 1987. Vida y Técnica en el Renacimiento: Manuscrito que escribió, en el siglo XVI, Francisco Lobato vecino de Medina del Campo. Valladolid: Universidad de Valladolid, Secretariado de Publicaciones.

Gottschalk, J. 2007. “Technische Verbesserungsvorschläge im Oberharzer Bergbau." In Gottfried Wilhelm Leibniz. Das Wirken des grossen Universalgelehrten als Philosoph, Mathematiker, Physiker, Techniker (2nd edition), edited by E. Stein and P. Wriggers, 109-132. Hannover, S.: Leibniz Universität Hannover.

Group for History of Science and Technology at Tsinghua University Library 清華大學圖書館科 技史研究組. 1983. Zhongguo kejishi ziliao xuanbian: Nongye jixie 中國科技史資料選編: 農業機械 [Collection of Selected Sources on the History of Science and Technology in Ancient China: Agricultural Machinery] (Section on hydraulic machines): 146-228. Beijing: Tsinghua University Press.

Gruter, Konrad von Werden. [1424] 2006. De machinis et rebus mechanicis: Ein Maschinenbuch aus Italien für den König von Dänemark 1393-1424, edited by Dietrich Lohrmann, Horst Kranz, and Ulrich Alertz. 2 vols. Città del Vaticano: Biblioteca Apostolica Vaticana.

Guidobaldo [Giuidobaldo] del Monte. 1577. Mechanicorum Liber. Apud Hieronymum Concordiam, Pisauri [Pisa]. 
Guidobaldo [Guido Ubaldo] del Monte. 1615. De Cochlea Libri Quatuor. Venetiis: Apud Evangelistam Deuchinum.

Halsberghe, Nicole. 2011. "Introduction and Development of the Screw in Seventeenth-Century China: Theoretical Explanations and Practical Applications by Ferdinand Verbiest." EASTM 34:163-193.

Janata, Alfred, Josef Kreiner, Erich Pauer, and Klaus Müller. 1972. “Bewässerung (mizu-hiki) und Bewässerungsgeräte: Bodenbaugeräte Japans IV.” Archiv für Völkerkunde 26:59-117.

Kink, Sabine. 2019. "Beistand für die himmlischen Kräfte: Pumpentechnik in Sabatino de Ursis' Taixi shuifa 泰西水法 (Hydromethoden des Grossen Westens, 1612)." Agricola-Forschungszentrum Chemnitz 27. Rundbrief:25-42.

Koenig, A. 2014. "Western books on hydraulics in the historic Beitang Library of the Jesuits in Beijing, China (1583-1773)". In E-Proceedings, IWA Regional Symposium on Water, Wastewater and Environment: Traditions and Culture. March 22-24, 2014. Patras, Greece.

Koenig, A. 2015. "Giulio Aleni S.J. (1582-1649) and the introduction of Western water supply methods to 17th century China." In E-Proceedings 4th IWA International Symposium on Water and Wastewater in Ancient Civilizations (WWAC2016). September 19-21, 2016. Coimbra, Portugal. Paper ID_24.

Koenig, A. 2018. "Hydrotechnical activities of Ferdinand Verbiest S.J. and other Jesuits in China." In Catholicism's Encounters with China: 17th to 20th Century, edited by Alexander Chen TsungMing, 31-63. Leuven Chinese Studies 39. KU Leuven, Belgium: Ferdinand Verbiest Institute.

Korean Minjok Leadership Academy. 2013. "History of Water-Power in Korea, in Comparison with China and Europe." Last modified October 22, 2013. https://www.zum.de/whkmla/ sp/1314/lsi/lsilog.html\#26.

Koutsier, Teun, and Hendrik Blauwendraat. 2004. "The Archimedean screw pump: A note on its invention and the development of the theory." In Proceedings of International Symposium on the History of Machines and Mechanisms (HMM2004), edited by Yan Hong-Sen and Marco Ceccarelli, 181-194. Dordrecht: Kluwer.

Krinsky, Carol Herselle. 1967. "Seventy-eight Vitruvius manuscripts." Journal of the Warburg and Courtauld Institutes 30:36-70.

Kwong, Luke S. 2001. "Self and society in modern China: Liu E (1857-1909) and 'Laocan youji.'” T'oung Pao, second series, vol. 87, fasc. 4/5.

Kyeser, Konrad. [1405] 1967. Bellifortis, Band 1: Facsimile-Druck der Pergament-Handschrift Cod. Ms. philos. 63 der Niedersächsischen Staats- und Universitätsbibliothek Göttingen. Edited by Georg-Agricola-Ges. zur Förderung der Geschichte der Naturwissenschaften und der Technik. Düsseldorf: VDI-Verlag.

Lamberini, Daniela. 2011. “'Sic virtus.' Il codice di macchine di Cosimo Bartoli.” In Cosimo Bartoli (1503-1572): Atti del Convegno internazionale (Mantova, 18-19 novembre; Firenze, 20 novembre 2009), edited by Francesco Paolo Fiore and Daniela Lamberini, 141-243. Firenze: Olschki.

Leibniz, Gottfried Wilhelm. 2006. Der Briefwechsel mit den Jesuiten in China (1689-1714), edited by Rita Widmaier and translated by Malte-Rudolf Babin, 10-25. Französisch/lateinisch-deutsch. Hamburg: Felix Meiner Verlag.

Lentzsch, Susann. 2018. "Die japanische Bildrolle mit Bergbaudarstellungen des Stadt- und Bergbaumuseums Freiberg." In Mitteilungen des Freiberger Altertumsvereins 111/112:129-163. 
Lohrmann, Dietrich. 2006. “Die archimedische Schraube in der Geschichte der menschlichen Arbeit bis ins 15. Jh." In Arbeit im Mittelalter, Vorstellungen und Wirklichkeiten, edited by Verana Postel, 171-186. Berlin: De Gruyter Akademie Forschung.

Maeda, Kiyoshi. 1983. “Nihon no ryubisha ni tsuite" 日本の竜尾車について[On the Archimedean screw in Japan]. Tamagawa daigaku kobakuyu kibo 玉川大学工学部紀要 [Memoirs of the College of Engineering, Tamagawa University] 18:25-48.

Mao, Yuanyi 茅元儀. [1621] 1984. Wubei Zhi 武備志 [Treatise on Armament Technology] juan 136. Taipei: Huashi Press 華世出版社.

Mathias, Regine. 2013. "Picture scrolls as historical source in Japanese mining." In Mining, Monies, and Culture in Early Modern Societies: East Asian and Global Perspectives, edited by Nanny Kim and Keiko Nagase-Reimer, 291-310. Leiden: Brill.

Nagase-Reimer, Keiko. 2013. “Water drainage in the mines of Tokugawa Japan: Technological improvements and economic limitations." In Mining, Monies, and Culture in Early Modern Societies: East Asian and Global Perspectives, edited by Nanny Kim and Keiko Nagase-Reimer, 25-42. Leiden: Brill.

Nakai, Chikuzan 中井竹山. [1789] 1915. Sobokigen 草芽危言 [Bold Words of Grasses and Reeds, also translated as Civilian Critiques on National Politics]. In Nihon Keizai sosho 日本経済叢書 [Series on the Japanese Economy], edited by Takimoto Seiichi 瀧本誠一, vol. 16:259-490. Tokyo: Nihon Keizai sosho kankokai 日本経済叢書刊行会.

Netto, C. 1879. "On mining and mines in Japan." Memoirs of the Science Department vol. 2. Tokyo: University of Tokyo.

Nishikawa, Joken 西川如見. 1731. Hyakusho bukuro 百姓囊 [A Farmer's Companion]. Kyoto. https://dl.ndl.go.jp/info:ndljp/pid/758177/29.

Nuernbergk, Dirk M. 2017. "Archimedes screw in the twenty-first century." In Archimedes in the 21st Century: Proceedings of a World Conference at the Courant Institute of Mathematical Sciences, edited by Chris Rorres, 113-124. Cham: Birkhäuser Science (Springer International Publishing).

Oba, Osamu. 1996. "Sino-Japanese relations in the Edo Period (Part Three: The Discovery of Banned Books)," translated by Joshua A. Fogel. Sino-Japanese Studies 9 (1): 56-74.

Oka, Motojí dit Oka, Tōen. ca. 1885-1895. “Sado Kōzan Kyūshiki Kōgyō-zu." Bibliothèque patrimoniale numérique de l’École nationale supérieure des mines de Paris (Mines ParisTech). Accessed April 6, 2020. https://patrimoine.mines-paristech.fr/document/Rouleau_Mines _Sado.

Oleson, John Peter. 1984. Greek and Roman Mechanical Water-Lifting Devices: The History of a Technology. Toronto: University of Toronto Press.

Paipetis, S. A., and M. Ceccarelli, eds. 2010. The Genius of Archimedes-23 Centuries of Influence on Mathematics, Science and Engineering. History of Machines and Machine Science Volume 11. Dordrecht: Springer.

Pak, Chi-wŏn. [1792] 2010. The Jehol diary: Yŏrha ilgi of Pak Chiwŏn (1737-1805), translation with notes and introduction by Yang Hi Choe-Wall, 159-160. Folkestone, UK: Global Oriental. [Translation of chapters 1-3 out of 26 chapters of original work printed in 1792].

Pseudo-Juanelo. ca. 1595. Los Veínte Y Un Libros de los Ingenios, Y Maquinas de Iuanelo, los quales le Mando escribir y Demostrar el Chatolico Rei D. Felipe Segundo Rey de las Hespañas y Nuebo Mundo (1595 +- 10), tomo iii, libro 13:609-612. Bibliotheca Digital Hispánica. Available at http://bdh- 
rd.bne.es/viewer.vm?id=0000099602\&page=1.

Qiu, Chunlin 邱春林. 2005. “Longweiche de yingyong shi ji wenhua shengtai kaoping” 龙尾车的 应用史及文化生态考评 [A Study on the Application History and Culture Ecology of Longweiche]. Xinyang shifan xueyuan xuebao (zhexue shehui kexue ban) 信阳师范学院学报 (哲学社 会科学版） [Journal of Xinyang Normal University (Philosophy and Social Science Edition)] 25 (5): 52-55.

${ }^{*}$ Ramelli, A. 1588. Le diverse et artificiose machine del capitano Agostino . . . ; composte in lingua Italiana et Francese. A Parigi in casa del'autore [Paris].

Rorres, Chris. 1995. "Archimedes." www.math.nyu.edu/ crorres/Archimedes/Screw/Sources Screw.html.

Rorres, Chris. 2000. "The Turn of the Screw: Optimal Design of an Archimedean Screw." Journal of Hydraulic Engineering 126 (1): 72-80.

Rorres, Chris, ed. 2017. Archimedes in the 21st Century: Proceedings of a World Conference at the Courant Institute of Mathematical Sciences. Cham: Birkhäuser Science (Springer International Publishing).

Sado-gun Kyōikukai. [1637] 1935. Sado nendaiki 佐渡年代記 上巻 [Chronicle of the Sado years, vol. 1] (寬永十四年). Sado: Sado-gun Kyōikukai.

Schreck, Johann, SJ, and Wang Zheng 王徵. [1628] 1830. Yuanxi qiqi tushuo luzui 遠西奇器圖說錄 最 (often abridged as Qiqi tushuo) [Illustrations and Descriptions of Extraordinary Devices]. Yangzhou. Institute for the History of Natural Sciences, Chinese Academy of Sciences. Also available at http://echo.mpiwg-berlin.mpg.de/ECHOdocuView?url=/mpiwg/online/per manent/archimedes/schre_qiqit_X03_zh_1627\&viewMode=image\&pn=1.

Seo, Ho-su 徐浩修. [1790] 2013. Rehe jiyou 熱河紀遊 [Journey to Jehol]. Guilin: Guangxi Normal University Press.

Simms, Dennis L. 1995. “Archimedes the Engineer." In History of Technology. London, UK: Continuum International Publishing Group.

Simms, D. L. 2010a. "Adventures of an innovation over two millenia: The water-screw and its variants: Part I Origins and Designs." Atti Della Fondazione Giorgio Ronchi LXV (2): 197-215.

Simms, D. L. 2010b. "Adventures of an innovation over two millenia: The water-screw and its variants: Part II In and out of Use." Atti Della Fondazione Giorgio Ronchi LXV (4): 487-502.

Simms, D. L. 2010c. "Adventures of an innovation over two millenia: The water-screw and its variants, Part III Back in uses." Atti Della Fondazione Giorgio Ronchi LXV (5): 642-678.

So, Senshun 曾占春, and Shirao [Kunihashira Saizo] Kokuchu 白尾國柱, eds. 1804. Seikei Zusetsu 成形圖說 [Illustrated Explanations of the Forms of Things] 30 vols. Kagoshima: Satsumakugaku. http://dl.ndl.go.jp/info:ndljp/pid/2546020.

Soto Artuñedo, Wenceslao, SJ. 2018. “El P. Diego de Pantoja en la Chrono-historia de Bartolomé Alcázar [Chrono-historia de la Provincia de Toledo de la Compañía de Jesús, por el R. P. Alcázar de la misma Compañía. 1586-1590. Capitulo IV]." In Diego de Pantoja, SJ (1571-1618). Un puente con la China de los Ming, coord. by Wenceslao Soto Artuñedo SJ, 65-148. Aranjuez: Xerión. Available at www.academia.edu/37352663/Diego_de_Pantoja_SJ_1571-1618_._Un_ puente_con_la_China_de_los_Ming.

Standaert, Nicolas. 2003. "The transmission of Renaissance culture in seventeenth-century China." Renaissance Studies 17 (3): 367-391. 
Su, Yunmeng 苏云梦, and Shi Yunli 石云里. 2017. “Longweiche tishui xiaoneng yanjiu-jianlun Ming Qing shiqi Ouzhou longweiche yuanhe weineng qudai Zhongguo longguche” 龙尾车提 水效能研究——兼论明清时期欧洲龙尾车缘何未能取代中国龙骨车 [A Research on the Waterlifting Efficiency of the Archimedean Screw: Why It Failed to Take the Place of the Traditional Chinese Water-lifting Device in the Ming-Qing Era]. Zhongguo nongshi 中国农史 [Agricultural History of China] (2): 125-134.

Sugimoto, Masayoshi, and David L. Swain. 1978. Science and Culture in Traditional Japan (A.D. 6001854). Cambridge, Massachusetts, and London, England: MIT Press.

Sukekawa, Karino. 1800. Sado kinzan emaki. Provo, Utah: Brigham Young University.

Taqi al-Din. 1551. Al-Turuq al-Saniya fí al-'ālat al-rūhaniya [Sublime methods of spiritual machines] Manuscript No. 5232 of Chester Beatty Library, Dublin.

Thiel, Ulrich. 2004. "Eine japanische Bildrolle mit Bergbaudarstellung-Bedeutender Neuzugang im Stadt- und Bergbaumuseum Freiberg." Der Anschnitt 56 (2-3): 110-113.

Todd, Hamish. 1998. "The British Library's Sado Mining Scrolls." British Library Journal 24 (1): 130-143.

Traetta, Luigi. 2019. "Giuseppe Ceredi. A Hydraulic Engineer in 16th-Century Italy." In Explorations in the History and Heritage of Machines and Mechanisms, Proceedings of the 2018 HMM IFToMM Symposium on History of Machines and Mechanisms, edited by Zhang Baichun and Marco Ceccarelli, 17-27. Cham, Switzerland: Springer Nature Switzerland.

Treptow, Emil. 1904. "Der altjapanische Bergbau und Hüttenbetrieb, dargestellt auf Rollbildern.” Jahrbuch für das Berg- und Hüttenwesen im Königreiche Sachsen. Jahrgang 1904, edited by C. Menzel, 149-160. Freiberg: Craz \& Gerlach.

Treptow, Emil. 1918. "Der älteste Bergbau und seine Hilfsmittel." In Beiträge zur Geschichte der Technik und Industrie: Jahrbuch des Vereines Deutscher Ingenieure-8, edited by Conrad Matschoss, 155-191. Berlin: VDI-Verlag.

University of Tours. n.d. Architectura: architecture, textes, et images (XVIe-XVIIe siècles). Books on Architecture. Accessed February 13, 2020. http://architectura.cesr.univ-tours.fr/traite/Aute ur/Vitruve.asp?param $=$ en.

Ursis, Sabatino de, SJ, and Xu Guangqi 徐光啟. 1612. Taixi shuifa 泰西水法 [Hydraulic Methods of the Far West] 6 juan. National Library of China. Available at https://www.wdl.org/en/ item/13534/.

Valturio, Roberto. 1472. De re militari. Verona: Johannes Nicolai de Verona.

Vegetius Renatus, Flavius. 1529. Vier Bücher der Ritterschaft, 117. Augsburg: Steiner [= German Translation of Latin Epitoma rei militaris or De re militari].

Verhaeren, Hubert. 1949. Catalogue de la Bibliotheque du Pe-t'ang. Pekin: Imprimerie des Lazaristes.

Vitruvius. 1960. The Ten Books on Architecture, translated by Morris Hickey Morgan. New York: Dover Publications [This is a new release of the original 1914 edition, one of the earliest and best English translations].

Walravens, Hartmut. 2016. "Das Buch von den wunderbaren Maschinen." In Johannes SchreckTerrentius SJ: Wissenschaftler und China-Missionar (1576-1630), edited by Claudia von Collani and Erich Zettl, 159-181. Stuttgart: Franz Steiner Verlag.

Winkelmann, Heinrich. 1957. "Das Sado-Goldbergwerk auf Japanischen Rollbildern." Der Anschnitt 9 (4): 20-25. 
Winkelmann, Heinrich. 1964. Altjapanischer Goldbergbau und Hüttenbetrieb auf Sado. Handkolorierte Reproduktionen nach einem Bildwerk in der Bibliothek des Deutschen Museums in München. Wechthin/Lünen: Eisenhütte Westfalia.

Xie, Xiuqing 解秀清. 2006. Yuanmingyuan youlan shouce 圆明园游览手册 [Touring manual for the Summer Palace]. Beijing: Forbidden City Press.

Yi, Ik. 1976. Sŏngho sasŏl 星湖僿說. Sŏul Tŭkpyŏlsi: Kyŏngmunsa.

Zhang, Baichun 张柏春. 2017. “Transmission, Cooperation and Competition in Device Construction between China and Europe in 16th-18th Centuries." Nova Acta Leopoldina NF Nr. 414:99-111.

Zhang, Baichun, and Tian Miao 田滎. 2009. “Wang Zheng (1571-1644).” In Distinguished Figures in Mechanism and Machine Science: Their Contributions and Legacies Part II, edited by Marco Ceccarelli, 247-259. Dordrecht: Springer.

Zhang, Baichun, and Tian Miao. 2010. "Archimedean Mechanical Knowledge in 17th Century China." In The Genius of Archimedes-23 Centuries of Influence on Mathematics, Science and Engineering, edited by Stephanos A. Paipetis and Marco Ceccarelli, 189-205. Dordrecht: Springer.

Zou, Zhenhuan 鄒振環. 2017. “Zhongxi shuiwenhua hudong zhong de 'bian' yu 'chang': Yi Taixi shuifa zai Ming Qing Jiangnan diqu de chuanbo wei li” 中西水文化互動中的 “變” 與 “常”: 以《泰西水法》在明清江南地區的傳播爲例 [On the “Changing” and “Laggard" Elements in the Interaction of Water Culture between China and the West: A Case Study of the Transmission of Hydraulic Methods of the Far West in the Jiangnan area of the Ming and Qing Dynasties]. Nanguo xueshu 南國學術 [South China Quarterly] 7 (3): 395-413. 


\section{Appendixes}

\section{Appendix 1: Vitruvius's chapter on the water screw, in Latin and English translation}

\section{Caput Sextum}

[1] Est autem etiam cocleae ratio, quae magnam vim haurit aquae, sed non tam alte tollit quam rota. Eius autem ratio sic expeditur. Tignum sumitur, cuius tigni quanta rata est pedum longitudo, tanta digitorum expeditur crassitudo. Id ad circinum rutundatur. In capitibus circino dividentur circumitiones eorum tetrantibus et octantibus in partes octo, eaeque lineae ita conlocentur, ut plano posito tigno utriusque capitis ad libellam lineae inter se respondeant, et quam magna pars sit octava circinationis tigni, tam magna spatia decidantur in longitudinem. Item tigno plano conlocato lineae ab capite at alterum caput perducantur ad libellam convenientes. Sic et in rotundatione et in longitudine aequalia spatia fient. Ita quod loci describuntur lineae, quae sunt in longitudinem spectantes, facient decusationes et in decusationibus finita puncta.

[2] His ita emendate descriptis sumitur salignea tenuis aut de vitice secta regula, quae uncta liquida pice figitur in primo decusis puncto. Deinde traicitur oblique ad insequentes longitudinis et circumitionis decusis, item ex ordine progrediens singula puncta praetereundo et circum involvendo conlocatur in singulis decusationibus, et ita pervenit et figitur ad eam lineam recedens a primo in octavum punctum, in qua prima pars est eius fixa. Eo modo quantum progreditur oblique spatium et per octo puncta, tantundem et longitudine procedit ad octavum punctum. Eadem ratione per omne spatium longitudinis et rutunditatis singulis decusationibus oblique fiixae regulae per octo crassitudinis divisiones involutos faciunt canales et iustam cocleae naturalemque imitationem.

[3] Ita per id vestigium aliae super alias figuntur unctae pice liquida, et exaggerantur ad id, uti longitudinis octava pars fiat summa crassitudo. Supra eas circumdantur et figuntur tabulae, quae pertegant eam involutionem. Tunc eae tabulae pice saturantur et lamminis ferreis conligantur, ut ab aquae vi ne dissolvantur. Capita tigni ferrea. Dextra autem ac sinistra cocleam tigna conlocantur in capitibus utraque parte habentia transversaria confixa. In his foramina ferrea sunt inclusa inque ea inducuntur styli, et ita cocleae hominibus calcantibus faciunt versationes.

[4] Erectio autem eius ad inclinationem sic erit conlocanda, uti, quemadmodum Pythagoricum trigonum orthogonium describitur, sic id habeat responsum, id est uti dividatur longitudo in partes $\mathrm{V}$, earum trium extollatur caput cocleae; ita erit ab perpendiculo ad imas naris spatium earum partium IIII. Qua ratione autem oporteat id esse, in extremo libro eius forma descripta est in ipso tempore.

Quae de materia fiunt organa ad hauriendam aquam, quibus rationibus perficiantur quibusque rebus motus recipientia praestent versationibus ad infinitas utilitate ut essent notiora, quam apertissime potui, perscripta sunt in illo tempore.

Barbaro, Daniele. 1567. De architectura libri decem, cum Commentariis Danielis Barbari . . . liber 10, caput 6. Venetiis: Apud Franciscum, Franciscum Senensem \& Ioan Crugher Germanum. 


\section{The water screw}

1. There is also the method of the screw, which raises a great quantity of water, but does not carry it as high as does the wheel. The method of constructing it is as follows. A beam is selected, the thickness of which in digits is equivalent to its length in feet.

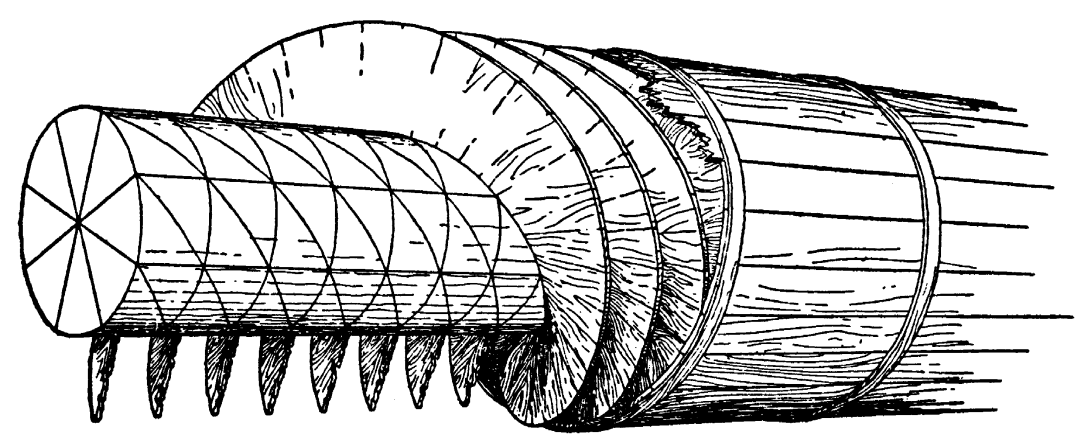

Construction of the water screw

This is made perfectly round. The ends are to be divided off on their circumference with the compass into eight parts, by quadrants and octants, and let the lines be so placed that, if the beam is laid in a horizontal position, the lines on the two ends may perfectly correspond with each other, and intervals of the size of one eighth part of the circumference of the beam may be laid off on the length of it. Then, placing the beam in a horizontal position, let perfectly straight lines be drawn from one end to the other. So the intervals will be equal in the directions both of the periphery and of the length. Where the lines are drawn along the length, the cutting circles will make intersections, and definite points at the intersections.

2. When these lines have been correctly drawn, a slender withe of willow, or a straight piece cut from the agnus castus tree, is taken, smeared with liquid pitch, and fastened at the first point of intersection. Then it is carried across obliquely to the succeeding intersections of longitudinal lines and circles, and as it advances, passing each of the points in due order and winding round, it is fastened at each intersection; and so, withdrawing from the first to the eighth point, it reaches and is fastened to the line to which its first part was fastened. Thus, it makes as much progress in its longitudinal advance to the eighth point as in its oblique advance over eight points. In the same manner, withes for the eight divisions of the diameter, fastened obliquely at the intersections on the entire longitudinal and peripheral surface, make spiral channels which naturally look just like those of a snail shell.

3. Other withes are fastened on the line of the first, and on these still others, all smeared with liquid pitch, and built up until the total diameter is equal to one eighth of the length. These are covered and surrounded with boards, fastened on to protect the spiral. Then these boards are soaked with pitch, and bound together with strips of iron, so that they may not be separated by the pressure of the water. The ends of the shaft are covered with iron. To the right and left of the screw are beams, with crosspieces fastening them together at both ends. In these crosspieces are holes sheathed with iron, and into them pivots are introduced, and thus the screw is turned by the treading of men. 
4. It is to be set up at an inclination corresponding to that which is produced in drawing the Pythagorean right-angled triangle: that is, let its length be divided into five parts; let three of them denote the height of the head of the screw; thus the distance from the base of the perpendicular to the nozzle of the screw at the bottom will be equal to four of those parts. A figure showing how this ought to be, has been drawn at the end of the book, right on the back.

I have now described as clearly as I could, to make them better known, the principles on which wooden engines for raising water are constructed, and how they get their motion so that they may be of unlimited usefulness through their revolutions.

Vitruvius. 1914. "The Water Screw." In The Ten Books on Architecture book 10, chapter 6, sections 1-4, translated by Morris Hicky Morgan. Cambridge: Harvard University Press; London: Humphrey Milford; Oxford: Oxford University Press. 


\section{Appendix 2: Sado Island Gold Mining Scrolls outside Japan}

\begin{tabular}{|c|c|c|c|}
\hline & No. & AS & Source \\
\hline \multicolumn{4}{|l|}{ Germany } \\
\hline Freiberg Stadt- und Bergbaumuseum & 3 & no & (Treptow 1904) \\
\hline Freiberg Stadt- und Bergbaumuseum & 1 & AS-1, AS-2 & (Thiel 2004; Lentzsch 2018) \\
\hline Berlin Ethnologisches Museum & 3 lost & AS-3 & (Treptow 1904) \\
\hline München Museum Five Continents & 1 & n.a. & (Treptow 1904) \\
\hline München Deutsches Museum & 2 & AS-1 & (Winkelmann 1964) \\
\hline Bochum Bergbaumuseum & 2 & no & (Winkelmann 1957) \\
\hline Staatsbibliothek zu Berlin & 1 & AS-3 & $\begin{array}{l}\text { https://digital.staatsbibliothek- } \\
\text { berlin.de/werkansicht?PPN=PPN16887982 } \\
\text { 0X\&PHYSID=PHYS_000116 }\end{array}$ \\
\hline \multicolumn{4}{|l|}{ Switzerland } \\
\hline Bern Schweizerisches Bundesarchiv & 1 & no & (FDFA 2016, 153-161) \\
\hline \multicolumn{4}{|l|}{ France } \\
\hline Paris Mines Tech & 1 & AS-1 & $\begin{array}{l}\text { https://patrimoine.mines- } \\
\text { paristech.fr/document/Rouleau_Mines_Sa } \\
\text { do }\end{array}$ \\
\hline \multicolumn{4}{|l|}{ UK } \\
\hline H. J. Osborne White, geologist & 1 & AS-3 & (Bromehead 1942) \\
\hline London British Library & 3 & AS-1 & (Todd 1998) \\
\hline Michael Jones & 1 & n.a. & (Ford and Brown 1995) \\
\hline Michael West & 1 & n.a. & (Ford and Brown 1995) \\
\hline London, Royal School of Mines & 1 & n.a. & (Ford and Brown 1995) \\
\hline \multicolumn{4}{|l|}{ USA } \\
\hline Boston, Burndy Library, MIT & 2 & n.a. & (Ford and Brown 1998) \\
\hline Boston, MIT Museum & 3 & n.a. & (Ford and Brown 1998) \\
\hline Provo, Harold B. Lee Library & 2 & AS-1 & (Sukekawa 1800) \\
\hline \multicolumn{4}{|l|}{ Ireland } \\
\hline Dublin, Chester Beatty Library & 1 & AS-3 & (Chester Beatty Library 2012, 17) \\
\hline \multicolumn{4}{|l|}{ Australia } \\
\hline Sydney, Art Gallery of NSW & 1 & AS-3 & $\begin{array}{l}\text { https://www.artgallery.nsw.gov.au/collec } \\
\text { tion/works/342.2001/ }\end{array}$ \\
\hline \multicolumn{4}{|l|}{ Other } \\
\hline On offer by bookseller & 2 & AS-3 & (Jonathan A. Hill Catalogue 2017) $^{17}$ \\
\hline
\end{tabular}

Note: AS = contains drawing of Archimedean screw; AS-1, AS-2, and AS-3 = single, double, and triple Archimedean screw shown; no = no drawing of Archimedean screw shown; n.a. = no information known about possible drawing of Archimedean screw.

16 Persistent URL: http://resolver.staatsbibliothek-berlin.de/SBB0002B37300000000.

17 Jonathan A. Hill, bookseller, Catalogue 2017, Items 43 and 44. https://ilab.org/sites/default/files/catalogs / files/JAHill\%20Cat\%20221\%20Japanese\%20\&\%20Chinese\%20Books, \%20Scrolls, \%20\&\%20MSS.pdf. 